\title{
Review Article \\ Implication of Fructans in Health: Immunomodulatory and Antioxidant Mechanisms
}

\author{
Elena Franco-Robles and Mercedes G. López \\ Centro de Investigación y de Estudios Avanzados del IPN, Unidad Irapuato, Km 9.6 Libramiento Norte Carretera Irapuato-León, \\ 36821 Irapuato, GTO, Mexico
}

Correspondence should be addressed to Mercedes G. López; mlopez@ira.cinvestav.mx

Received 23 October 2014; Revised 29 January 2015; Accepted 6 March 2015

Academic Editor: Aida Turrini

Copyright (C) 2015 E. Franco-Robles and M. G. López. This is an open access article distributed under the Creative Commons Attribution License, which permits unrestricted use, distribution, and reproduction in any medium, provided the original work is properly cited.

\begin{abstract}
Previous studies have shown that fructans, a soluble dietary fiber, are beneficial to human health and offer a promising approach for the treatment of some diseases. Fructans are nonreducing carbohydrates composed of fructosyl units and terminated by a single glucose molecule. These carbohydrates may be straight or branched with varying degrees of polymerization. Additionally, fructans are resistant to hydrolysis by human digestive enzymes but can be fermented by the colonic microbiota to produce short chain fatty acids (SCFAs), metabolic by-products that possess immunomodulatory activity. The indirect role of fructans in stimulating probiotic growth is one of the mechanisms through which fructans exert their prebiotic activity and improve health or ameliorate disease. However, a more direct mechanism for fructan activity has recently been suggested; fructans may interact with immune cells in the intestinal lumen to modulate immune responses in the body. Fructans are currently being studied for their potential as "ROS scavengers" that benefit intestinal epithelial cells by improving their redox environment. In this review, we discuss recent advances in our understanding of fructans interaction with the intestinal immune system, the gut microbiota, and other components of the intestinal lumen to provide an overview of the mechanisms underlying the effects of fructans on health and disease.
\end{abstract}

\section{Introduction}

Fructans are recognized as health-promoting food ingredients. They are found in a small number of mono- and dicotyledonous families of plants, such as Liliaceae, Amaryllidaceae, Gramineae, Compositae, Nolinaceae, and Agavaceae. Various fructan-containing plant species, including asparagus, garlic, leek, onion, Jerusalem artichoke, and chicory roots, are often eaten as vegetables [1-3]. Substantial variation in chemical and structural conformations makes fructans a flexible and appealing ingredient for different dietary products such as nutraceuticals.

Inulin-type fructans (ITFs) are among the most studied; ITFs are indigestible, fully soluble, fermentable food ingredients with known prebiotic properties. ITFs are linear fructose polymers with $\beta(2 \rightarrow 1)$ linkages found naturally in chicory roots, wheat, onion, garlic, and other foods. In the scientific literature, ITFs are frequently referenced generically but inconsistently as "inulin," "oligofructose" (OF), and "fructooligosaccharides" (FOS) [4]. Agave fructans have a more complex, highly branched structure, including $\beta(2 \rightarrow 1)$ and $\beta(2 \rightarrow 6)$ linkages. Thus, Agave fructans can contain an external glucose, characteristic of graminans, and an internal glucose, characteristic of neofructans. For this reason, this type of fructans has been called "agavins" [5].

Fructans contribute to host health through multiple mechanisms. Fructans are selective substrates for probiotic bacteria stimulating probiotic bacterial growth, which can confer health benefits to the host through the several mechanisms, including immunomodulation [6-8]. Fructans may also act as scavengers of reactive oxygen species [9], decreasing inflammation and improving redox status. Fructans are fermented to short chain fatty acids (SCFAs), which have important implications in host health. In addition, direct interaction between fructans and intestinal immune cells has recently been suggested. The aim of this review is to summarize the latest findings on studies investigating fructans as prebiotics and to provide an overall image of the mechanisms underlying the health effects of fructans. 


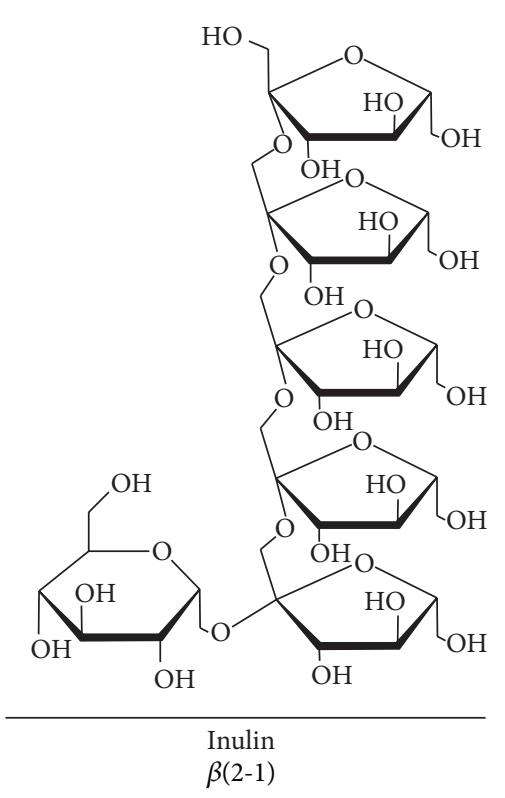

(a)

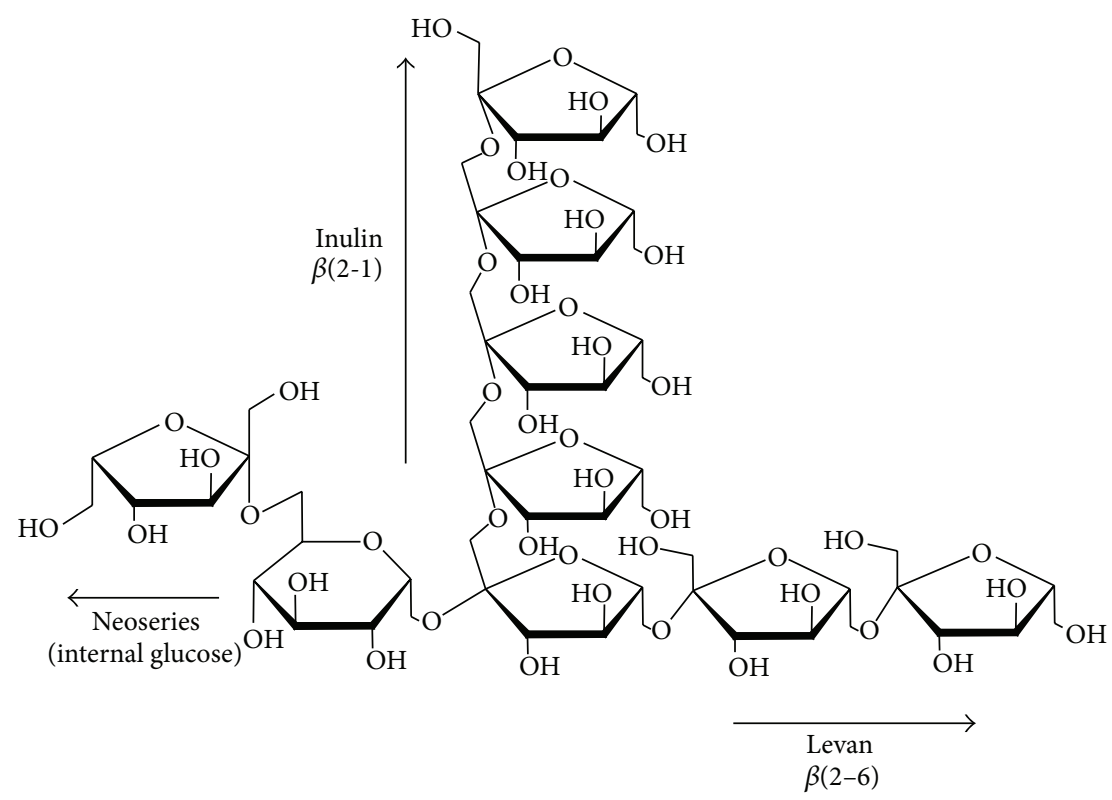

(b)

FIGURE 1: Structural comparison of the (a) inulin from Cichorium intybus and (b) agavin from Agave spp.

\section{Fructans: Structure, Source, and Synthesis}

Approximately $15 \%$ of flowering plants store fructans as reserve carbohydrates [10]. Worldwide, the most studied and marketed fructan is inulin, which is obtained primarily from chicory roots. However, some candidate fructans, such as galactooligosaccharides (GOS) derived from lactose and lactulose, have also demonstrated potential prebiotic effects [11]. In addition to chicory root, another potential fructan source includes the more recently investigated Agave fructans. The Agave tequilana Weber azul variety is an economically important species of Agave cultivated in Mexico. Because of its high inulin concentration, this variety is the only species in the Agavaceae family that is appropriate for tequila production. The high inulin concentrations, specifically in the head (pine), provide added economic and environmental value to this species of Agave [12].

Fructans have been classified into 4 groups based on their structural bonds: inulin, levans, graminans, and neoseries fructans (inulin neoseries and levan neoseries mixture) [13]. Inulin is the simplest linear fructan, consisting of $\beta(2 \rightarrow 1)$ linked fructose residues. Inulin is usually found in plants such as Cichorium intybus (15-20\% fructans), Jerusalem artichoke (15-20\% fructans), Helianthus tuberosus (15-20\% fructans), and Dahlia variabilis (15-20\% fructans) (Figure 1) [13-15]. Levan-type fructans (also called phleins in plants) can be found in grasses (Poaceae). Levan fructans contain a linear $\beta(2 \rightarrow 6)$-linked fructose polymer and are found in big bluegrass (Poa secunda) [16,17]. Graminan-type fructans consist of $\beta(2 \rightarrow 6)$-linked fructose residues with $\beta(2 \rightarrow 1)$ branches or can consist of more complex structures in which neosugars are combined with branched fructan chains. These complex fructans are usually found in plants such as Avena sativa, Lolium sp., and Agave sp. (15-22\% fructans) (Figure 1)
$[5,18-20]$. The inulin neoseries are linear (2-1)-linked $\beta$ d-fructosyl units linked to both $\mathrm{C} 1$ and $\mathrm{C} 6$ on the glucose moiety of the sucrose (Suc) molecule. This results in a fructan polymer with a fructose chain ((mF2-1F2-6G1-2F12Fn); F (fructose), G (glucose)) on both ends of the glucose molecule. These fructans are found in plants belonging to the Liliaceae family (e.g., onion and asparagus (10-15\% fructans)) $[15,21]$. The smallest inulin neoseries molecule is called neokestose. The levan neoseries consists of polymers with predominantly $\beta(2 \rightarrow 6)$-linked fructosyl residues on either end of the glucose moiety of the sucrose molecule. These fructans are rare, although they have been found in a few plant species belonging to the Poales (e.g., oat) [18].

The length of fructosyl chains varies greatly in plants; plant fructosyl chains are much shorter than those of bacterial fructans. In general, the chain length or degree of polymerization (DP) is between 30 and 50 fructosyl residues in plants but can occasionally exceed 200 [13]. Fructans can also be classified according to their DP into small (2 to 4), medium (5 to 10 ), and relatively large chain lengths (11 to 60 fructose units). The term fructooligosaccharides (FOS) is used for short fructans with a DP of 3-5 derived from sucrose [22]; oligofructose $(\mathrm{OF})$ is used for molecules with a DP of 3-10 derived from native inulin [23].

The biosynthesis of fructans begins with sucrose (Suc), to which fructose residues are added [4]. In plants, fructans are synthesized from Suc by the action of two or more enzymes known as fructosyltransferases. The first enzyme, 1-SST (sucrose:sucrose fructosyltransferase), initiates de novo fructan synthesis by catalyzing the transfer of a fructosyl residue from one Suc molecule to another, resulting in the formation of the trisaccharide 1-kestose. The second enzyme, 1-FFT (fructan:fructan 1-fructosyltransferase), transfers fructosyl residues from a fructan molecule with a DP of $\leq 3$ 
to either another fructan molecule or a Suc. The actions of 1-SST and 1-FFT result in the formation of a mixture of fructan molecules with different chain lengths [13].

\section{Functional Effects of Fructans}

Worldwide, over $60 \%$ of functional food products are directed toward intestinal health, and additional therapeutic benefits of these products to human health are constantly being explored. Prebiotics are defined as "selectively fermented ingredients that allow specific changes, both in the composition and/or activity in the gastrointestinal microbiota that confers benefits upon host well-being and health" [24]. Moreover, prebiotics may suppress pathogen growth to improve overall health [25]. Current evidence indicates that beneficial bacteria reduce the risk of diseases through diverse mechanisms, including modulation of gut microbiota composition or function, and regulation of host epithelial and immunological responses. These effects may be revealed through changes in bacterial populations or metabolic activity [26]. Bacterial metabolism can confer a number of advantageous effects to the host, including the production of vitamins, modulation of the immune system, enhancement of digestion and absorption, inhibition of harmful bacterial species, and removal of carcinogens and other toxins. The resident microbiota is also known to consist of pathogens that can disrupt normal gut function and predispose the host toward disease if allowed to overgrow [27].

Fructans play protective roles in plants subjected to drought, salt, or cold stress [14]. However, the therapeutic potential of fructans in human health has only recently been explored. As described above, fructans are the most widely known and used prebiotics [28]. Of the many nondigestible food ingredients studied for their prebiotic potential, human trials favor ITFs, FOS, OF, and GOS [29-32]. Fructans have been proposed as modulators of the microbial ecology and host physiology in animals and humans $[33,34]$ because they are not digested [9]. Although they are subjected to minor hydrolysis in the stomach, the human gut lacks the hydrolytic enzymes capable of digesting $\beta$ linkages [35]. Therefore, fructans reach the colon relatively intact and eventually trigger a decrease in the $\mathrm{pH}$, thereby altering the colonic environment [36]. The rate and extent of ITFs fermentation appear to be strongly influenced by the DP. FOS (low DP) are rapidly fermented in the proximal colon [37], whereas inulin (high DP) appears to have a more sustained fermentation profile that potentially enables protective effects in the distal colon $[4,38]$. Acting as prebiotics, inulin, FOS, and GOS improve glucose, reduce triglycerides, modify lipid metabolism, and reduce plasma LPS. Additionally, they stimulate Lactobacillus and Bifidobacterium species to reduce the presence of pathogens in the gut and relieve constipation (Table 1). Other fructans, including soluble gut oligosaccharides, mimic the sugar chains found in the glycoproteins and glycolipids of gut epithelial cells, thereby preventing the adhesion of pathogenic microorganisms [39] and exerting direct antimicrobial effects [40] (Table 1).

Interestingly, fructans from Dasylirion spp. (DAS) and A. tequilana Gto. (TEQ) increased SCFAs production and decreased colon $\mathrm{pH}$ in in vitro studies [41]. Furthermore, supplementation of the mouse diet with Agave fructans (TEQ and DAS) has been shown to increase secretion of GLP-1 and its precursor, proglucagon mRNA, in all colonic segments of the mouse. These results suggest that fermentable fructans of different botanical origins and with differing chemical structures are able to promote the production of satietogenic/incretin peptides in the lower part of the gut [41] (Table 1). Moreover, Agave fructans have been shown to have physiological effects on lipid metabolism $[41,42]$ and reduce oxidative stress in conjunction with phenolic compounds in in vitro and in vivo assays [42] (Table 1). For the first time, the effect of agavins from Agave angustifolia and Agave potatorum as prebiotics has been reported showing satiety effect as well as an increment on GLP-1 and a decrement on ghrelin in an animal model [43] (Table 1).

Studies have been performed to determine whether probiotics reduce cancer risk. To maximize the effect of a prebiotic compound, the prebiotic would need to ferment in the distal colon, where proteolytic fermentation predominates and toxic metabolites such as ammonia, hydrogen sulfide, and cresol are produced [44, 45]. A recent study by Gomez et al. was the first to investigate the effect of Agave fructan fermentation on complex fecal microbiota in vitro [46] (Table 1). The first clinical trial in humans with Agave fructans was very promising, as Agave treatment improved laxation [47]. Other carbohydrates, including glucooligosaccharides, isomaltooligosaccharides, lactulose, mannanoligosaccharides (MOS), nigerooligosaccharides, oat $\beta$-glucans, raffinose, soybean oligosaccharides, transgalactooligosaccharides, and xylooligosaccharides, are considered candidate prebiotics [31, 48]; however, more research is required.

\section{Immunomodulatory Effects of Fructans}

The consumption of prebiotics can modulate immune parameters in gut-associated lymphoid tissue (GALT), secondary lymphoid tissues, and peripheral circulation [70]. GALT functions to distinguish between harmful and innocuous agents and protects against infections while simultaneously avoiding the generation of hypersensitivity reactions to commensal bacteria and harmless antigens [71-73]. In inductive GALT, more structured and localized sites of antigen processing and presentation are distinguished in areas such as Peyer's patches (PPs), mesenteric lymph nodes (MLNs), the appendix, and isolated lymph nodes. GALT also contains effector sites with more diffuse organization, containing previously activated and differentiated cells that performed effector functions (Figure 2). Joint activity of the inductive and effector sites generates a rich response in immunoglobulin A (IgA) and cellular immunity, with robust cytotoxic regulatory functions and memory at the level of the mucosa and serum [74]. The intestinal epithelium provides a physical barrier that separates the trillions of commensal bacteria in the intestinal lumen from the underlying lamina propria (LP) and the deeper intestinal layers. Microfold cells (M cells), B cells (especially IgA-producing plasma cells), T cells, macrophages, and dendritic cells (DCs) in the LP are located 
TABLE 1: Main prebiotic effects of fructans in in vitro and in vivo studies.

\begin{tabular}{|c|c|c|c|c|c|}
\hline Effect & $\begin{array}{l}\text { Type of } \\
\text { fructan }\end{array}$ & Dose/duration & Model & Results & Reference \\
\hline $\begin{array}{l}\text { Decreasing blood } \\
\text { glucose }\end{array}$ & FOS, inulin & $\begin{array}{l}8 \mathrm{~g} / \mathrm{d} \text { for } 14 \text { days; } \\
10 \% \text { for } 4 \text { weeks }\end{array}$ & $\begin{array}{l}\text { Diabetic } \\
\text { subjects; animal } \\
\text { models }\end{array}$ & $\begin{array}{l}\text { Significant reduction of mean fasting } \\
\text { blood glucose levels. Improving glucose } \\
\text { tolerance }\end{array}$ & {$[49-51]$} \\
\hline $\begin{array}{l}\text { Reduction in blood } \\
\text { serum } \\
\text { triacylglycerol } \\
\text { levels }\end{array}$ & FOS, inulin & $\begin{array}{l}4-34 \mathrm{~g} / \mathrm{d} \text { for } \\
21-60 \text { days; } 10 \% \\
\text { for } 3-5 \text { weeks }\end{array}$ & $\begin{array}{l}\text { Healthy } \\
\text { humans; obese } \\
\text { animal models }\end{array}$ & $\begin{array}{l}\text { Significant reduction in blood serum } \\
\text { triacylglycerol levels }\end{array}$ & {$[52-54]$} \\
\hline $\begin{array}{l}\text { Improved lipid } \\
\text { metabolism }\end{array}$ & $\begin{array}{l}\text { FOS, GOS, } \\
\text { inulin, and } \\
\text { agavins }\end{array}$ & $\begin{array}{l}5 \%-10 \% \text { for } 21 \\
\text { day to } 8 \text { weeks }\end{array}$ & $\begin{array}{l}\text { Obese animal } \\
\text { models }\end{array}$ & $\begin{array}{l}\text { Decrease in body weight gain. Decrease } \\
\text { in epididymal adipose tissue, inguinal } \\
\text { adipose tissue, and subcutaneous adipose } \\
\text { tissue. Reducing fat-mass development }\end{array}$ & $\begin{array}{l}{[41,50,51} \\
55-59]\end{array}$ \\
\hline $\begin{array}{l}\text { Stimulation of } \\
\text { lactobacilli and } \\
\text { bifidobacteria and } \\
\text { decreasing } \\
\text { pathogens }\end{array}$ & $\begin{array}{l}\text { FOS, GOS, } \\
\text { and inulin }\end{array}$ & $\begin{array}{l}2.5-34 \mathrm{~g} / \mathrm{d} \text { for } \\
14-64 \text { days }\end{array}$ & $\begin{array}{l}\text { Healthy subjects } \\
\text { and animal } \\
\text { models }\end{array}$ & $\begin{array}{l}\text { Stimulating the growth of bifidobacteria } \\
\text { and contributing to the suppression of } \\
\text { potential pathogenic bacteria }\end{array}$ & {$[46,60,61]$} \\
\hline $\begin{array}{l}\text { Relief of } \\
\text { constipation }\end{array}$ & $\begin{array}{l}\text { Inulin, FOS, } \\
\text { and GOS }\end{array}$ & $\begin{array}{l}20-40 \mathrm{~g} / \mathrm{d} \text { for } 19 \\
\text { days }\end{array}$ & $\begin{array}{l}\text { Constipated } \\
\text { humans and } \\
\text { animal models }\end{array}$ & $\begin{array}{l}\text { Inulin showing a better laxative effect } \\
\text { than lactose and reducing functional } \\
\text { constipation with only mild discomfort }\end{array}$ & {$[62,63]$} \\
\hline $\begin{array}{l}\text { Increased } \\
\text { production of } \\
\text { SCFAs and } \\
\text { decreasing colon } \\
\mathrm{pH}\end{array}$ & $\begin{array}{l}\text { Inulin, FOS, } \\
\text { and agavins }\end{array}$ & $\begin{array}{l}24 \mathrm{~g} / \mathrm{d} \text { for } 5 \\
\text { weeks; } 10 \% \text { for } \\
28 \text { days }\end{array}$ & $\begin{array}{l}\text { Healthy } \\
\text { subjects; animal } \\
\text { models }\end{array}$ & $\begin{array}{l}\text { Significant increase of acetate, } \\
\text { propionate, and butyrate. Significantly } \\
\text { increasing activity of bacterial enzymes } \\
\text { and decreasing the pH of digesta }\end{array}$ & {$[36,64,65]$} \\
\hline $\begin{array}{l}\text { Improving mineral } \\
\text { uptake }\end{array}$ & $\begin{array}{l}\text { Inulin, FOS, } \\
\text { and agavins }\end{array}$ & $\begin{array}{l}1-40 \mathrm{~g} / \mathrm{d} \text { for } 9 \\
\text { days; } \\
50-100 \mathrm{~g} / \mathrm{kg} \text { diet } \\
\text { for } 4 \text { weeks }\end{array}$ & $\begin{array}{l}\text { Male healthy } \\
\text { adolescents; } \\
\text { animal models }\end{array}$ & $\begin{array}{l}\text { FOS stimulating fractional calcium } \\
\text { absorption in male adolescents. A } \\
\text { combination of different carbohydrates } \\
\text { showing synergistic effects on intestinal } \\
\text { Ca absorption and balance in rats }\end{array}$ & {$[66-69]$} \\
\hline $\begin{array}{l}\text { Regulated gut } \\
\text { peptides }\end{array}$ & $\begin{array}{l}\text { Inulin, FOS, } \\
\text { and agavins }\end{array}$ & $\begin{array}{l}24 \mathrm{~g} / \mathrm{d} \text { for } 5 \\
\text { weeks; } 10 \% \text { for } 5 \\
\text { weeks }\end{array}$ & $\begin{array}{l}\text { Healthy } \\
\text { subjects; } \\
\text { animals models }\end{array}$ & $\begin{array}{l}\text { Increasing plasma glucagon-like } \\
\text { peptide-1 (GLP-1) concentrations and } \\
\text { reducing ghrelin. Increasing endogenous } \\
\text { GLP-2 production and consequently } \\
\text { improving gut barrier functions }\end{array}$ & $\begin{array}{l}{[36,41,50,} \\
57,59]\end{array}$ \\
\hline $\begin{array}{l}\text { Reducing body } \\
\text { weight and energy } \\
\text { intake }\end{array}$ & Agavins & $10 \%$ for 5 weeks & $\begin{array}{l}\text { Male healthy } \\
\text { animal model }\end{array}$ & $\begin{array}{l}\text { Agave fructans showing indications of } \\
\text { prebiotic activity, particularly in relation } \\
\text { to satiety and GLP-1 and ghrelin } \\
\text { secretion. In this same study, the levels of } \\
\text { butyric acid were higher for } \\
\text { Agave potatorum fructans }\end{array}$ & {$[43]$} \\
\hline $\begin{array}{l}\text { Growth inhibition } \\
\text { and prevention of } \\
\text { adhesion of } \\
\text { pathogenic } \\
\text { microorganisms }\end{array}$ & FOS & $\begin{array}{l}170 \mathrm{mg} / \mathrm{kg}, 2 \\
\text { weeks of } \\
\text { lactation }\end{array}$ & $\begin{array}{l}\text { Breast-fed } \\
\text { infant; } \\
\text { cocultures of } \\
\text { Pseudomonas } \\
\text { aeruginosa }\end{array}$ & $\begin{array}{l}\text { Oligosaccharides in human milk } \\
\text { interfering with microbial adhesion. } \\
\text { Reduction of exotoxin A in cultures of } P \text {. } \\
\text { aeruginosa }\end{array}$ & {$[39,40]$} \\
\hline $\begin{array}{l}\text { Reduction of } \\
\text { oxidative stress by } \\
\text { reducing ROS } \\
\text { levels }\end{array}$ & FOS, agavins & $\begin{array}{l}10 \% \text { for } 4-8 \\
\text { weeks }\end{array}$ & $\begin{array}{l}\text { Male obese } \\
\text { animal models }\end{array}$ & $\begin{array}{l}\text { FOS reducing TBARS urine. } \\
\text { Lipopolysaccharides reduction in plasma. } \\
\text { Improving the redox status by reducing } \\
\text { the malondialdehyde serum levels and } \\
\text { protein oxidative damage }\end{array}$ & {$[9,42,65]$} \\
\hline $\begin{array}{l}\text { Stimulation of the } \\
\text { immune system }\end{array}$ & $\begin{array}{l}\text { FOS, GOS, } \\
\text { and inulin }\end{array}$ & & & & $\begin{array}{c}\text { See } \\
\text { Table } 2 .\end{array}$ \\
\hline
\end{tabular}

FOS: fructooligosaccharides; GOS: galactooligosaccharides; SCFAs: short chain fatty acids. 


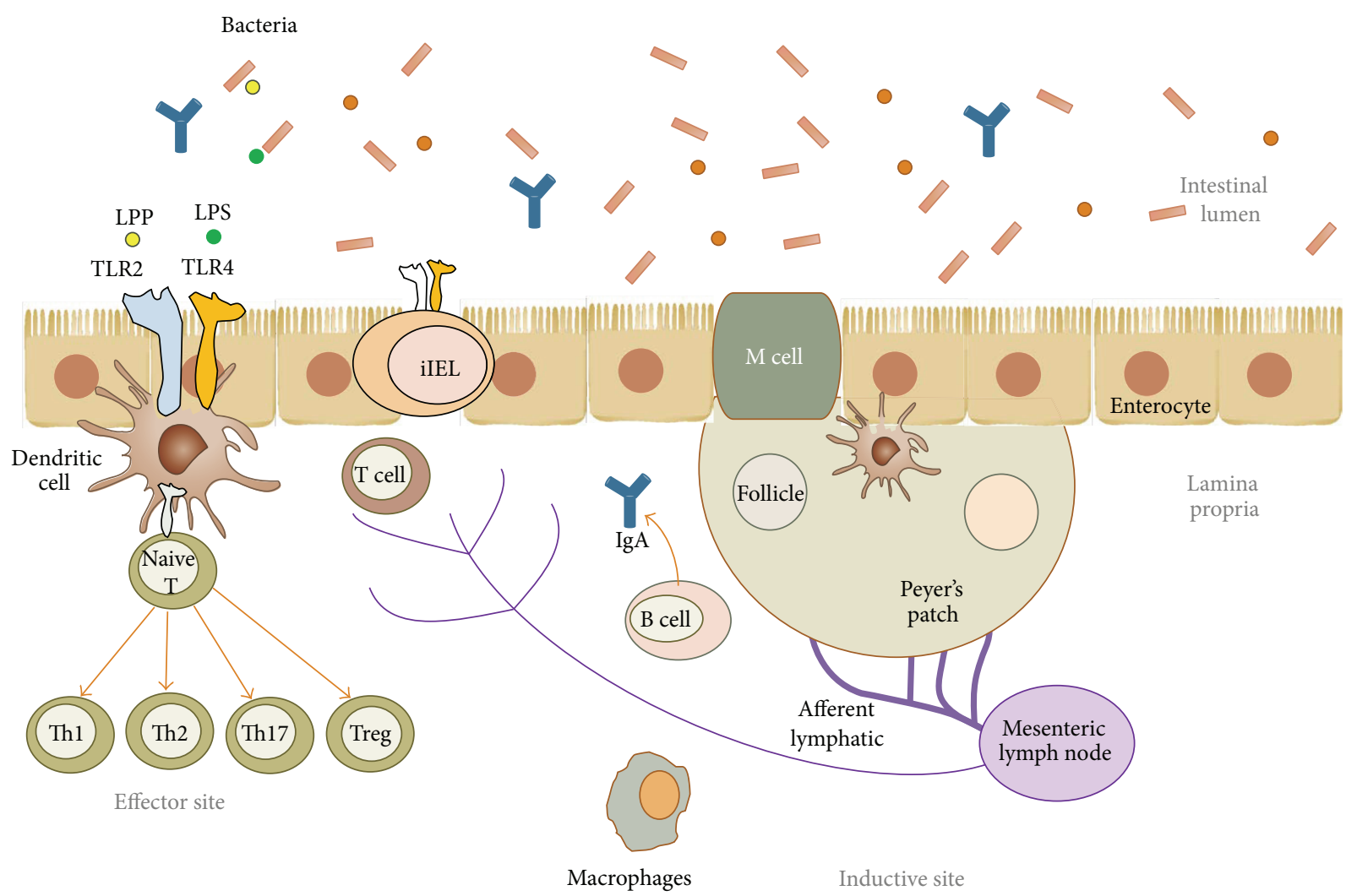

FIGURE 2: Induction of an immune response through gut-associated lymphoid tissue (GALT).

directly below the intestinal epithelium (Figure 2). M cells are part of the epithelial layer covering the PP and specialize in transporting antigens from the lumen to GALT [75].

$\mathrm{T}$ and $\mathrm{B}$ cells are activated after initial contact with the antigen at inductive sites. These cells then proliferate, differentiate, and migrate to various effector sites, such as the LP or the intestinal epithelium, where a single population of iIELs (intestinal intraepithelial lymphocytes) and some DCs are located between the enterocytes [76-78] (Figure 2).

In fact, iIELs provide a cellular defense against any individual antigen [79]. Meanwhile, DCs are potent antigenpresenting cells critical for the induction of downstream adaptive immune responses [80]. For instance, several subsets of DCs have been identified within the PP that possess either Th1- or Th2-polarizing ability [81]. The CD103+ subset has been found within the small intestinal LP, MLN, and PP, as well as the colonic LP. CD103+ DCs have FoxP3+ Tregpolarizing ability, as well as the ability to imprint gut-homing $\mathrm{T}$ cells; expression of the a $4 \mathrm{~b} 7$ integrin on conventional $\mathrm{T}$ cells and Treg cells involved in directing gut tropism ensures their ability to be imprinted $[82,83]$. CD103+ DC subsets have also been shown to induce Th17 polarization and IgA class switching [84, 85]. Moreover, all DC subsets and antigen-presenting cells, including macrophages, are equipped with a battery of pattern recognition receptors (PRRs). These receptors can detect molecular patterns of invading microorganisms or endogenous "danger" signals and stimulate the immune response. PRRs are expressed on the cell surface and intracellularly are extremely diverse and capable of detecting a wide range of molecular species, including proteins, carbohydrates, lipids, and nucleic acids [86]. The Toll-like receptor (TLRs) family is the most intensely studied family of PRRs on DCs. Triggering TLRs on DCs is thought to be critical for their functional maturation to immunogenic DCs and for their ability to prime naive $\mathrm{T}$ cells in response to infection. Therefore, TLR activation couples innate and adaptive immunity [87]. TLR-mediated recognition of commensal microorganisms may also play important roles in tissue homeostasis, as recent studies have shown that TLR signaling by DCs was required to maintain immune homeostasis and tolerance to gut microbiota [88]. Interestingly, Tregs are also abundant at host-microbiota interfaces. Studies have suggested that commensal microbiota can stimulate the generation of Tregs and Th17 cells [89]. These results highlight the importance of diet and the microbiota in the establishment and configuration of the immune system of the intestinal mucosa. However, whether prebiotic compounds directly affect immune components or whether they act exclusively through the modulation of the endogenous intestinal microbiota remains unclear.

4.1. Indirect Mechanisms of Fructan Health Effects. Prebiotics and probiotics may have indirect immunomodulatory functions through their actions on nonimmune cells, such as epithelial cells. However, they may also exert immune system-independent effects by selectively stimulating 
the growth and/or activity of beneficial intestinal bacteria, such as Lactobacillus and Bifidobacterium species, which results in the restoration of the normal composition of the intestinal microbiota [90]. Mutualism between the host and its microbiota is fundamental for maintaining homeostasis in a healthy individual [91]. Commensal bacteria provide the host with essential nutrients. They also metabolize indigestible compounds, defend against the colonization of opportunistic pathogens, and contribute to the development of intestinal architecture in addition to stimulating the immune system [92]. In fact, intestinal immune and metabolic homeostasis in mammals is largely maintained by interactions between the gut microbiota and GALT [93]. The host actively engages the gut microbiota and controls its composition by secreting antimicrobial peptides and immunoglobulins. Conversely, commensals shape the gutassociated immune system by controlling the prevalence of distinct $\mathrm{T}$ cell populations [94]. Bacteroides fragilis protects mice from infection by Helicobacter hepaticus through several immunological mechanisms, including suppression of IL-17 production [95]. These commensals also express capsular zwitterionic polysaccharide $\mathrm{A}$, which is a cognate antigen to effector $\mathrm{CD} 4^{+} \mathrm{T}$ cells [92]. Other zwitterionic polysaccharides, such as type 1 capsule of Streptococcus pneumoniae, can also modify inflammatory responses in animal models by stimulating IL-10-producing $\mathrm{CD} 4{ }^{+} \mathrm{T}$ cells [96]. Moreover, bacterial symbionts, such as Bacteroides, Barnesiella, and Turicibacter, interact with $\mathrm{CD}^{+}$cytotoxic T cells in the mucosal compartment of the small intestine and colon [97].

Other indirect pathways by which fructans exert immunomodulatory effects include the production of SCFAs, which are the fermentation products of fructans. Inulin fermentation increases the production of SCFAs (acetate, propionate, and butyrate), lactic acid, and hydrogen $\left(\mathrm{H}_{2}\right)$, while decreasing the $\mathrm{pH}$ of the colonic environment [36]. Bifidobacterium species are able to use some monosaccharides in a unique manner to ultimately generate SCFAs [98] and acidify the colonic environment. The increase in SCFAs antagonizes the growth of some pathogenic bacterial strains [99] and favors mucin production in the colon [100]. SCFAs bind to SCFAs receptors on GALT immune cells [101-103], activating G protein-coupled receptors (GPR) [104], such as GPR41 and GPR43 [101, 102, 104]. This binding affects the recruitment of leukocytes to inflammatory sites $[105,106]$ and suppresses the production of proinflammatory cytokines and chemokines [106-108]. GPR43 is highly expressed in polymorphonuclear cells (PMNs, i.e., neutrophils) and is lowly expressed in peripheral blood mononuclear cells (PBMCs) and purified monocytes. Conversely, GPR41 is expressed in PBMCs but not in PMNs, monocytes, or DCs [102]. Importantly, butyrate decreases the glutamine requirement for epithelial cells and alters epithelial cell gene expression $[71,109]$. The mechanism for the indirect effect of fructans on the immune system is shown in Figure 3.

4.2. Direct Mechanism: Pattern Recognition Receptors. In addition to the indirect effects of fructans and their fermentation products on the microbiota, the direct effects of fructans on the signaling of immune cells have gained attention as an additional pathway of immunomodulation. ITFs have been reported to interact directly with GALT components, such as gut dendritic cells (DCs) and intraepithelial lymphocytes (iIELs), through receptor ligation of PRRs [7]. Signaling through PRRs, such as TLRs (Tolllike receptors), is considered the starting point of innate immune system activation against various environmental factors, including microbes and antigens. The innate immune system enables appropriate adaptive immune responses to be generated through the activation of multiple specific immunocompetent clones [110]. TLRs play an important role in initial innate immune responses, which includes cytokine synthesis and activating acquired immunity. The $\beta(2 \rightarrow 1)$-linked fructans can provide a direct signal to human immune cells primarily by activating TLR2 and to a lesser extent TLR4, TLR5, TLR7, TLR8, and NOD2. $\beta(2 \rightarrow 1)$ linked fructans stimulation results in NF- $\kappa \mathrm{B} / \mathrm{AP}-1$ activation, further suggesting that $\beta(2 \rightarrow 1)$-fructans are specific ligands for TLR2. However, chain length is important for the induced activation pattern and IL-10/IL-12 ratios stimulated by $\beta(2 \rightarrow$ 1)-fructans [111, 112]. In fact, ITFs increase the proportion of DCs in PPs and increase the secretion of IL-2, IL-10, and interferon- $\gamma$ from the spleen and MLNs. Additionally, ITFs reduce the number and proportion of $\mathrm{T}$ cell receptor (TCR-) $\alpha \beta^{+} \mathrm{CD}^{+}$cells in the spleen and $\mathrm{CD} 45 \mathrm{RA}^{+}$cells in the MLNs [113] (Table 2). Furthermore, TLR4 appears to be involved in levan $\beta(2 \rightarrow 6)$-fructans pattern recognition. Oral administration of levans in vivo significantly reduced IgE serum levels and Th2 response in mice immunized with ovalbumin [8].

A fructose receptor may exist on immune cells, as receptors for $\beta$-glucan [114] and mannose [115] have been identified on the surface of immune cells. Oligofructose has also been shown to bind to receptors on pathogenic bacteria, preventing them from attaching to the epithelial membrane [116]. Furthermore, ITFs treatment of gut epithelial cells can modulate the innate immune barrier by modifying the integrity of epithelial tight junctions or by altering signals from the epithelial cells to the underlying immune cells [117].

Thirty-six fructan studies reporting immune outcomes have been conducted in mice, rats, pigs, dogs, and humans, and these investigations are summarized in Table 2. These reports show that fructans may have specific effects on different immune system components.

\section{Fructans Act as ROS Scavengers}

Because inulins and agavins have health benefits, improve blood metabolic parameters $[41,52]$, reduce colonic $\mathrm{pH}$ [152], increase SCFAs production [36, 43, 69], and stimulate the immune system [48], interest has developed in the antioxidant capacity of fructans. As in plants, fructans and other carbohydrates have been shown to scavenge ROS [153157]. ROS include free radicals such as the superoxide anion $\left(\mathrm{O}_{2}{ }^{\bullet-}\right)$, hydroxyl radical $\left({ }^{\circ} \mathrm{OH}\right)$, and nonradical molecules such as hydrogen peroxide $\left(\mathrm{H}_{2} \mathrm{O}_{2}\right)$ and singlet oxygen $\left({ }^{1} \mathrm{O}_{2}\right)$. These molecules attack DNA, lipids, and proteins resulting 


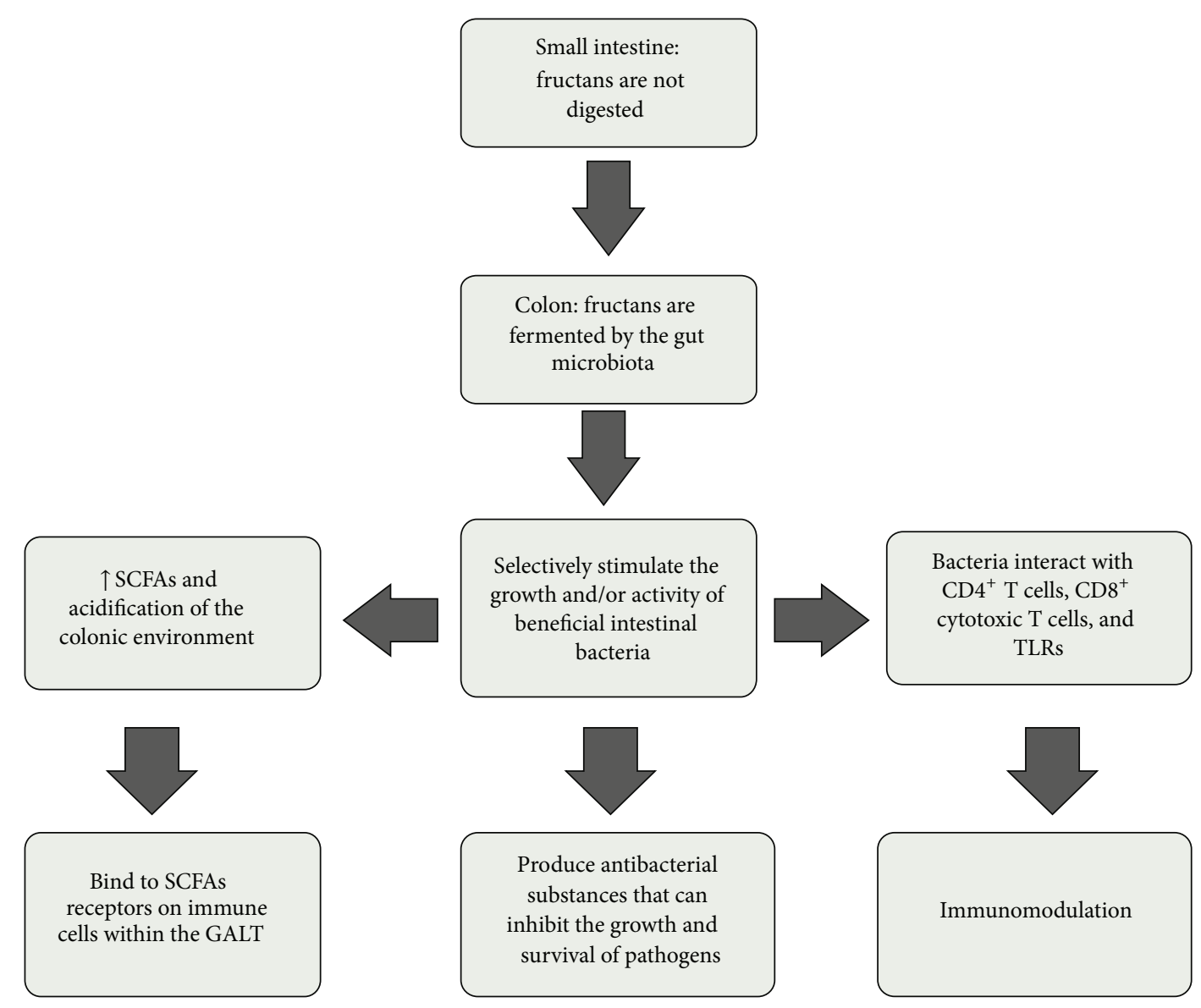

FIGURE 3: Mechanism for the indirect effect of fructans on the immune system.

in cellular damage [158]. Fructans, galactooligosaccharides (GOS), arabinoxylans, $\beta$-glucans, and fructooligosaccharides (FOS) might act as ROS scavengers in plants [159] because they have strong antioxidant activity in vitro. Raffinose appears to be a moderate ROS scavenger [160].

Recently reports have suggested that fructans possess antioxidant activity in in vivo models. A putative role for oligofructoses in counteracting the prooxidative effects of a high fructose diet has been demonstrated in rats. The addition of fructans to the diet may provide an early defense against oxidative stress and may act before the activation of the endogenous ROS detoxification systems [65]. In an indirect mechanism, these nondigestible carbohydrates might serve as ROS scavengers, which suggests that inulin can protect the colonic mucosa by acting as a barrier against oxidative stress in addition to its positive prebiotic effect. This hypothesis is consistent with the recently proposed ROS scavenging capability of inulin $[65,161]$ and the reported effects of SCFAs, which induce the expression of crucial antioxidant enzymes, such as glutathione S-transferases (GSTs) [162]. Li et al. showed that, in aged mice, synthetic oligosaccharides increase the activity of antioxidant enzymes [161]. By contrast, oligofructose has been shown to reduce the expression of NADPH oxidase in the colons of obese mice [51]. Moreover, intraperitoneal administration of synthetic oligosaccharides stimulates a dose-dependent decrease in lipid peroxidation, which supports the in vivo ROS scavenging capability of certain sugars [161]. Furthermore, agavins from Agave tequilana have been shown to improve the redox status in hypercholesterolemic mice by reducing malondialdehyde serum levels and oxidative protein damage. These results could be attributed to a reduction in the generation of oxidative products during digestion and colonic fermentation [42]. Additionally, polyphenol studies have indicated that metabolism in the large intestine is positively affected by prebiotic fructooligosaccharides, which have a synergistic effect with polyphenol to counteract oxidative stress in in vivo models [163].

\section{Conclusion}

Prebiotic consumption is undoubtedly associated with several health benefits. In this review, we assessed the potential immunomodulatory and antioxidants mechanisms of the prebiotic fructans as well as the impact of fructans on immune health. Some preliminary data have convincingly suggested that fructan consumption can modulate immune parameters in GALT. Additionally, fructans may act as ROS scavengers providing an increase in antioxidant defenses 
TABLE 2: Effect of fructans on the immune function in healthy animal and human models.

\begin{tabular}{|c|c|c|c|}
\hline Effects of fructans & $\begin{array}{l}\text { Dose } \\
\text { fructan/duration }\end{array}$ & Model & Reference \\
\hline $\begin{array}{l}\uparrow \mathrm{DC} \text { and } \gamma \delta \mathrm{T} \text { cells in lamina propria of the caecum and } \downarrow \\
\text { PGE2 in small intestine, colon, and caecum }\end{array}$ & $3 \%$ FOS for 12 days & $\begin{array}{l}\text { Mice treated with } \\
\text { antibiotics and } \\
\text { conventionalized with } \\
\text { Clostridium difficile }\end{array}$ & {$[118]$} \\
\hline $\begin{array}{l}\text { In peripheral blood: } \uparrow \mathrm{CD} 4^{+} / \mathrm{CD} 8^{+} \text {ratio and } \downarrow \text { B cells. In GALT: } \\
\uparrow \text { proportion of } \mathrm{CD} 4^{+} \text {cells and } \mathrm{CD} 8^{+} \text {cells, } \mathrm{PP} \text {, and lamina } \\
\text { propria cells and } \downarrow \mathrm{CD} 4^{+} / \mathrm{CD} 8^{+} \text {ratio in lamina propria }\end{array}$ & $\begin{array}{l}0.87 \% \text { FOS for } 14 \\
\text { days }\end{array}$ & Adult dogs & {$[119]$} \\
\hline Synbiotics $\uparrow$ whole blood phagocyte activation level. & $1 \%$ FOS for 28 days & $\begin{array}{l}\text { Piglets infected with } \\
\text { S. typhimurium }\end{array}$ & {$[120]$} \\
\hline $\begin{array}{l}\uparrow \text { counts of leucocytes, lymphocytes, neutrophils, } \mathrm{CD} 2^{+} \mathrm{T} \text { cells, } \\
\mathrm{CD} 4^{+} \mathrm{T} \text { cells, CD }{ }^{+} \mathrm{T} \text { cells, B cells, and macrophages in blood, } \uparrow \\
\% \text { phagocytic activity of leucocytes and neutrophils in blood. }\end{array}$ & $3 \mathrm{~g} / \mathrm{d}$ OF for 20 days & Newborn piglets & {$[121]$} \\
\hline$\uparrow$ ileal IgA concentration. & $\begin{array}{l}2 \mathrm{~g} / \mathrm{d} \text { FOS and/or } \\
\text { MOS for } 14 \text { days }\end{array}$ & Adult dogs & {$[122]$} \\
\hline$\downarrow$ blood neutrophils and $\uparrow$ blood lymphocytes. & $\begin{array}{l}2 \mathrm{~g} \text { FOS plus } / 1 \mathrm{~g} \\
\text { MOS for } 14 \text { days }\end{array}$ & Adult dogs & {$[123]$} \\
\hline $\begin{array}{l}\uparrow \text { rotavirus-specific IgA levels in serum and } \downarrow \text { duration of a } \\
\text { strong rotavirus-specific IgA response in faeces and \% IgA and } \\
\text { IgG positive B cell in the PP. } \uparrow \text { serum rotavirus-specific IgG and } \\
\text { Rhesus rotavirus antigen concentration in stools. }\end{array}$ & $\begin{array}{l}1.25 \mathrm{~g} / \mathrm{L} \text { OF for } 7 \\
\text { weeks }\end{array}$ & $\begin{array}{l}\text { Mice (pups) infected } \\
\text { with Rhesus rotavirus }\end{array}$ & {$[124]$} \\
\hline $\begin{array}{l}\text { No change in protein, alb, serum Ig, secreting IgA, and IL- } 4 \text { and } \\
\text { IFN- } \gamma \text { secretion, } \uparrow \text { antibodies against influenza B and } \\
\text { pneumococcus. }\end{array}$ & $\begin{array}{l}6 \mathrm{~g} \mathrm{OF} / \mathrm{ITF} \text { for } 28 \\
\text { weeks }\end{array}$ & $\begin{array}{l}\text { Healthy elderly }(>70 \\
\text { years) }\end{array}$ & {$[125]$} \\
\hline $\begin{array}{l}\uparrow \% \text { CD } 4 \text { and CD } 8 \text { lymphocytes, } \downarrow \text { phagocytic activity in } \\
\text { granulocytes and monocytes and IL- } 6 \text { mRNA expression in } \\
\text { PBMCs. }\end{array}$ & $8 \mathrm{~g} /$ day FOS, 3 weeks & $\begin{array}{l}\text { Nursing home elderly } \\
\text { (77-97 years) }\end{array}$ & {$[126]$} \\
\hline $\begin{array}{l}\uparrow \text { total faecal IgA, size of PP, total IgA secretion by PP cells and } \\
\text { IL- } 10 \text { and IFN- } \delta \text { production from PP CD } 4^{+} \text {T cells. }\end{array}$ & $\begin{array}{l}0-7.5 \% \text { FOS for } 6 \\
\text { weeks }\end{array}$ & Female mice & {$[127]$} \\
\hline $\begin{array}{l}\downarrow \text { leucocyte counts, } \uparrow \mathrm{NK} \text { activity of splenocytes and peritoneal } \\
\text { macrophage phagocytosis of Listeria monocytogenes. }\end{array}$ & $\begin{array}{l}2.5-10 \% \text { FOS or OF } \\
\text { for } 6 \text { weeks }\end{array}$ & Female mice & {$[128]$} \\
\hline $\begin{array}{l}\uparrow \text { total number of immune cells in PP, B lymphocytes in PP and } \\
\mathrm{T} \text { lymphocytes and } \mathrm{CD} 4^{+} / \mathrm{CD} 8^{+} \text {ratio in PP in endotoxemic } \\
\text { mice only. }\end{array}$ & $10 \%$ FOS for 16 days & $\begin{array}{l}\text { Female mice healthy } \\
\text { or endotoxemic }\end{array}$ & {$[129]$} \\
\hline$\downarrow$ peripheral blood lymphocyte concentration. & $\begin{array}{l}1 \% \text { ITFs/MOS for } 4 \\
\text { weeks }\end{array}$ & Senior dogs & {$[130]$} \\
\hline $\begin{array}{l}\uparrow \text { total intestinal IgA, ileal and colonic polymeric Ig receptor } \\
\text { expression, ileal IgA secretion rate, IgA response of PP cells, and } \\
\% \text { of } \mathrm{B}_{2} 20^{+} \operatorname{Ig} \mathrm{A}^{+} \text {cells. }\end{array}$ & $\begin{array}{l}5 \% \text { FOS for } 23-44 \\
\text { days }\end{array}$ & Newborn mice & {$[131]$} \\
\hline $\begin{array}{l}\uparrow \mathrm{IL}-10 \text { and IFN- } \delta \text { production in PP, secretory IgA } \\
\text { concentration in ileum and caecum. }\end{array}$ & $\begin{array}{l}\text { 10\% FOS-enriched } \\
\text { ITFs for } 4 \text { weeks }\end{array}$ & Male rats & {$[132]$} \\
\hline $\begin{array}{l}\uparrow \mathrm{NK} \text { activity. Prevention of the decrease in proportion of } \mathrm{T} \text { cells } \\
\text { with NK activity. }\end{array}$ & $\begin{array}{l}6 \mathrm{~g} / \mathrm{d} \text { OF and ITFs } \\
(2: 1 \text { ratio }) \text { for } 1 \text { year }\end{array}$ & $\begin{array}{l}\text { Elderly free-living } \\
\text { adults (age } \leq 70 \text { years) }\end{array}$ & {$[133]$} \\
\hline $\begin{array}{l}\text { Improved response to some vaccine components and increased } \\
\text { lymphocyte proliferation to influenza vaccine components. }\end{array}$ & $\begin{array}{l}\text { 4.95\% FOS for } 183 \\
\text { days }\end{array}$ & $\begin{array}{l}\text { Healthy adults (age } \leq \\
65 \text { years) }\end{array}$ & {$[134]$} \\
\hline $\begin{array}{l}\uparrow \mathrm{T} \text { cells, MHCII on antigen-presenting cells in spleen, MLN, } \\
\text { and thymus, IL- } 2 \text { and IL- } 4 \text { in blood. }\end{array}$ & $\begin{array}{l}10 \% \text { FOS/ITFs for } 4 \\
\text { months }\end{array}$ & Male rats & {$[135]$} \\
\hline Trend towards higher fecal sIgA. & $\begin{array}{l}0.6 \mathrm{~g} \\
(\mathrm{GOS} / \mathrm{FOS}) / 100 \mathrm{~mL} \\
\text { formula for } 32 \text { weeks }\end{array}$ & $\begin{array}{l}\text { Newborn } \\
\text { non-breast-fed infants }\end{array}$ & {$[136]$} \\
\hline $\begin{array}{l}\text { Improved response to } \uparrow \text { B cells, } \downarrow \text { memory cytotoxic T cells, } \uparrow \\
\text { influenza-activated lymphocytes (CD69 and CD25) and IL-6 } \\
\text { and } \downarrow \text { IL10. }\end{array}$ & $\begin{array}{l}4.95 \% \text { FOS for } 4 \\
\text { weeks }\end{array}$ & $\begin{array}{l}\text { Healthy adults (age } \leq \\
65 \text { years) }\end{array}$ & [137] \\
\hline
\end{tabular}


TABLe 2: Continued.

\begin{tabular}{|c|c|c|c|}
\hline Effects of fructans & $\begin{array}{l}\text { Dose } \\
\text { fructan/duration }\end{array}$ & Model & Reference \\
\hline $\begin{array}{l}\text { In pregnant females and pups no effect on serum IgG1, IgG2, } \\
\text { IgA, or IgM. In colostrum and milk } \uparrow \text { IgM. }\end{array}$ & $\begin{array}{l}0.1 \% \text { OF during } \\
\text { lactation }\end{array}$ & $\begin{array}{l}\text { Pregnant female dogs } \\
\text { and pups }\end{array}$ & {$[138]$} \\
\hline$\downarrow$ severity of enterocyte sloughing. & $\begin{array}{l}1 \% \text { FOS or ITFs for } \\
14 \text { days }\end{array}$ & Puppies & {$[139]$} \\
\hline $\begin{array}{l}\uparrow \% \mathrm{CD}^{19}(\mathrm{~B}) \text { cells, } \mathrm{CD}^{+} \mathrm{HLA}^{-\mathrm{DR}^{+}} \text {(activated T cells) and } \downarrow \% \\
\mathrm{ICAM}^{-1} \text { bearing lymphocytes and \% } \mathrm{CD}^{+} \mathrm{NK}^{+} \text {cells. }\end{array}$ & $\begin{array}{l}9 \mathrm{~g} / \mathrm{d} \text { ITFs for } 5 \\
\text { weeks }\end{array}$ & $\begin{array}{l}\text { Adults smokers and } \\
\text { nonsmokers }\end{array}$ & {$[140]$} \\
\hline $\begin{array}{l}\uparrow \text { vaccine-specific faecal IgA and plasma IgG levels, peritoneal } \\
\text { macrophage activity, mean fluorescence intensity of } \mathrm{MHCII}^{+} \\
\text {cells in spleen, IL-12 and IFN- } \delta \text { production by splenocytes, and } \\
\text { survival from Salmonella infection when given vaccine. }\end{array}$ & $\begin{array}{l}5 \% \operatorname{mix}(\text { ITFs, FOS, } \\
\text { and OF) for } 1 \text { week }\end{array}$ & Female mice & {$[141]$} \\
\hline$\uparrow$ fecal sIgA. & $\begin{array}{l}6 \mathrm{~g} / \mathrm{L} \text { GOS/FOS } \\
(9: 1) \text { for } 26 \text { weeks }\end{array}$ & $\begin{array}{l}\text { Newborn healthy } \\
\text { infants }\end{array}$ & {$[142]$} \\
\hline$\uparrow$ NK activity, and IL-10, $\downarrow$ IL- 6 , IL- $1 \beta$, and TNF- $\alpha$. & $\begin{array}{l}5.5 \mathrm{~g} \text { GOS/d for } 10 \\
\text { weeks }\end{array}$ & Elderly (64-79 years) & {$[143]$} \\
\hline $\begin{array}{l}\uparrow \mathrm{DCs} \text { in PP, } \uparrow \text { IL- } 2, \text { IL-10, and IFN- } \delta \text { from spleen and MNL } \\
\text { cells. } \downarrow \text { number and proportion of T cell receptor (TCR-) } \\
\alpha \beta^{+} \mathrm{CD} 8^{+} \text {cells in spleen and CD } 45 \mathrm{RA}^{+} \text {cells in MLN. }\end{array}$ & $5 \%$ ITFs for 4 weeks & Female rats & {$[113]$} \\
\hline $\begin{array}{l}\downarrow \text { total IgE, IgG1, IgG2, and IgG3; } \downarrow \text { cow’s milk protein-specific } \\
\text { IgG1. }\end{array}$ & $\begin{array}{l}8 \mathrm{~g} / \mathrm{L} \mathrm{GOS} / \mathrm{FOS} \text { for } 6 \\
\text { months }\end{array}$ & $\begin{array}{l}\text { Newborn infants at } \\
\text { risk for allergy }\end{array}$ & {$[144]$} \\
\hline$\downarrow$ intestinal sIgA. & $\begin{array}{l}2.51-0.42 \mathrm{~g} / \mathrm{kg} / \mathrm{d} \text { mix } \\
\text { of GOS, XOS, OF, } \\
\text { and ITFs } \\
(3.6: 1: 0.4: 5) \text { for } 12 \\
\text { days }\end{array}$ & $\begin{array}{l}\text { Female rats induced } \\
\text { with diphenoxylate }\end{array}$ & {$[145]$} \\
\hline$\downarrow$ IL- $1 \beta$ in macrophage cultures and $\uparrow$ fecal IgA. & $\begin{array}{l}3-5 \% \text { FOS for } 30 \\
\text { days }\end{array}$ & Female mice & {$[146]$} \\
\hline $\begin{array}{l}\downarrow \text { LPS in blood and } \downarrow \text { LPS-induced increases in gene expression } \\
\text { in IL- } 1 \beta \text { and LPS-induced decreases in gene expression in IL-13 } \\
\text { in blood. }\end{array}$ & $\begin{array}{l}5 \mathrm{~g} \text { XOS, ITFs-XOS } \\
(3: 1) \text { for } 4 \text { weeks }\end{array}$ & Healthy volunteers & {$[147]$} \\
\hline$\downarrow$ serum cortisol, TNF- $\alpha$ and IL-6 after a LPS injection. & $\begin{array}{l}0.10 \% \text { levan-type } \\
\text { fructan for } 42 \text { days }\end{array}$ & Growing pigs & {$[63]$} \\
\hline $\begin{array}{l}\uparrow \text { fecal secretory IgA and } \downarrow \text { fecal calprotectin and plasma } \\
\text { C-reactive protein. }\end{array}$ & $\begin{array}{l}5.5 \mathrm{~g} / \mathrm{d} \mathrm{B}-\mathrm{GOS} \\
\left(\mathrm{Bi}^{2} \text { muno }\right) \text { for } 12 \\
\text { weeks }\end{array}$ & Overweight adults & {$[148]$} \\
\hline $\begin{array}{l}\uparrow \text { TGF- } \beta \text { secretion by splenocytes and IFN- } \gamma \text { production and } \downarrow \\
\text { IL- } 5 \text {. }\end{array}$ & $\begin{array}{l}\text { GOS/ITFs (dose and } \\
\text { duration data not } \\
\text { shown) }\end{array}$ & Healthy mice & {$[149]$} \\
\hline $\begin{array}{l}\downarrow \text { CD16/56 on natural killer T cells and } \downarrow \text { IL-10 secretion, XOS } \\
\text { and Bi-07 supplementation } \downarrow \text { CD19 on B cells. }\end{array}$ & $\begin{array}{l}8 \mathrm{~g} \text { XOS or with } 10^{9} \\
\text { CFU Bi-07/d for } 21 \\
\text { days }\end{array}$ & $\begin{array}{l}\text { Healthy adults }(25-65 \\
\text { years })\end{array}$ & {$[150]$} \\
\hline $\begin{array}{l}\uparrow \text { cell-mediated immunity in terms of skin indurations and } \\
\mathrm{CD} 4^{+} \text {T-lymphocyte population. }\end{array}$ & $\begin{array}{l}20-60 \mathrm{~g} / \mathrm{kg} \\
\text { FOS/ITFs for } 12 \\
\text { weeks }\end{array}$ & Healthy rats & [151] \\
\hline
\end{tabular}

partially through the activation of endogenous ROS detoxification systems. Further studies will be required to fully understand and elucidate the mechanisms of action for fructans on GALT in various disease models.

\section{Conflict of Interests}

The authors declare that there is no conflict of interests regarding the publication of this paper. 


\section{References}

[1] M. G. Lopez, N. A. Mancilla-Margalli, and G. Mendoza-Diaz, "Molecular structures of fructans from Agave tequilana Weber var. azul," Journal of Agricultural and Food Chemistry, vol. 51, no. 27, pp. 7835-7840, 2003.

[2] J. van Loo, P. Coussement, L. de Leenheer, H. Hoebregs, and G. Smits, "On the presence of inulin and oligofructose as natural ingredients in the western diet," Critical Reviews in Food Science and Nutrition, vol. 35, no. 6, pp. 525-552, 1995.

[3] C. J. Pollock and A. J. Cairns, "Fructan metabolism in grasses and cereals," Annual Review of Plant Physiology and Plant Molecular Biology, vol. 42, no. 1, pp. 77-101, 1991.

[4] G. Kelly, "Inulin-type prebiotics-a review: part 1," Alternative Medicine Review, vol. 13, no. 4, pp. 315-329, 2008.

[5] N. A. Mancilla-Margalli and M. G. Lopez, "Water-soluble carbohydrates and fructan structure patterns from Agave and Dasylirion species," Journal of Agricultural and Food Chemistry, vol. 54, no. 20, pp. 7832-7839, 2006.

[6] C.-C. Tsai, C.-R. Lin, H.-Y. Tsai et al., "The immunologically active oligosaccharides isolated from wheatgrass modulate monocytes via toll-like receptor-2 signaling," The Journal of Biological Chemistry, vol. 288, no. 24, pp. 17689-17697, 2013.

[7] L. Vogt, D. Meyer, G. Pullens et al., "Immunological properties of inulin-type fructans," Critical Reviews in Food Science and Nutrition, vol. 55, no. 3, pp. 414-436, 2014.

[8] Q. Xu, T. Yajima, W. Li, K. Saito, Y. Ohshima, and Y. Yoshikai, "Levan ( $\beta$-2, 6-fructan), a major fraction of fermented soybean mucilage, displays immunostimulating properties via Toll-like receptor 4 signalling: induction of interleukin-12 production and suppression of T-helper type 2 response and immunoglobulin E production," Clinical \& Experimental Allergy, vol. 36, no. 1, pp. 94-101, 2006.

[9] W. van den Ende, D. Peshev, and L. de Gara, "Disease prevention by natural antioxidants and prebiotics acting as ROS scavengers in the gastrointestinal tract," Trends in Food Science and Technology, vol. 22, no. 12, pp. 689-697, 2011.

[10] G. A. F. Hendry, "Evolutionary origins and natural functions of fructans - a climatological, biogeographic and mechanistic appraisal," New Phytologist, vol. 123, no. 1, pp. 3-14, 1993.

[11] A. Cardelle-Cobas, N. Corzo, A. Olano, C. Peláez, T. Requena, and M. Ávila, "Galactooligosaccharides derived from lactose and lactulose: influence of structure on Lactobacillus, Streptococcus and Bifidobacterium growth," International Journal of Food Microbiology, vol. 149, no. 1, pp. 81-87, 2011.

[12] G. Iniguez-Covarrubias, R. Díaz-Teres, R. Sanjuan-Duenas, J. Anzaldo-Hernández, and R. M. Rowell, "Utilization of byproducts from the tequila industry. Part 2: potential value of Agave tequilana Weber azul leaves," Bioresource Technology, vol. 77, no. 2, pp. 101-108, 2001.

[13] I. Vijn and S. Smeekens, "Fructan: more than a reserve carbohydrate?” Plant Physiology, vol. 120, no. 2, pp. 351-359, 1999.

[14] T. Ritsema and S. Smeekens, "Fructans: beneficial for plants and humans," Current Opinion in Plant Biology, vol. 6, no. 3, pp. 223230, 2003.

[15] N. Kaur and A. K. Gupta, "Applications of inulin and oligofructose in health and nutrition," Journal of Biosciences, vol. 27, no. 7, pp. 703-714, 2002.

[16] N. J. Chatterton and P. A. Harrison, "Fructan oligomers in Poa ampla," New Phytologist, vol. 136, no. 1, pp. 3-10, 1997.

[17] J.-Z. Wei, N. J. Chatterton, P. A. Harrison, R. R.-C. Wang, and S. R. Larson, "Characterization of fructan biosynthesis in big bluegrass (Poa secunda)," Journal of Plant Physiology, vol. 159, no. 7, pp. 705-715, 2002.

[18] D. P. Livingston, N. J. Chatterton, and P. A. Harrison, "Structure and quantity of fructan oligomers in oat (Avena spp.)," New Phytologist, vol. 123, no. 4, pp. 725-734, 1993.

[19] I. M. Sims, C. J. Pollock, and R. Horgan, "Structural analysis of oligomeric fructans from excised leaves of Lolium temulentum," Phytochemistry, vol. 31, no. 9, pp. 2989-2992, 1992.

[20] N. Pavis, N. J. Chatterton, P. A. Harrison et al., "Structure of fructans in roots and leaf tissues of Lolium perenne," New Phytologist, vol. 150, no. 1, pp. 83-95, 2001.

[21] N. Shiomi, "Properties of fructosyltransferases involved in the synthesis of fructan in liliaceous plants," Journal of Plant Physiology, vol. 134, no. 2, pp. 151-155, 1989.

[22] I. G. Carabin and W. Gary Flamm, "Evaluation of safety of inulin and oligofructose as dietary fiber," Regulatory Toxicology and Pharmacology, vol. 30, no. 3, pp. 268-282, 1999.

[23] M. B. Roberfroid, "Concepts in functional foods: the case of inulin and oligofructose," Journal of Nutrition, vol. 129, no. 7, pp. 1398S-1401s, 1999.

[24] M. B. Roberfroid, "Inulin-type fructans: functional food ingredients," Journal of Nutrition, vol. 137, no. 11, supplement, pp. 2493S-2502S, 2007.

[25] M. B. Roberfroid, "Prebiotics: preferential substrates for specific germs?” American Journal of Clinical Nutrition, vol. 73, no. 2, supplement, pp. 406S-409S, 2001.

[26] M. E. Sanders, F. Guarner, R. Guerrant et al., "An update on the use and investigation of probiotics in health and disease," Gut, vol. 62, no. 5, pp. 787-796, 2013.

[27] S. Kolida and G. R. Gibson, "Prebiotic capacity of inulin-type fructans," Journal of Nutrition, vol. 137, no. 11, supplement, pp. 2503S-2506S, 2007.

[28] S. H. Al-Sheraji, A. Ismail, M. Y. Manap, S. Mustafa, R. M. Yusof, and F. A. Hassan, "Prebiotics as functional foods: a review," Journal of Functional Foods, vol. 5, no. 4, pp. 1542-1553, 2013.

[29] G. R. Gibson, H. M. Probert, J. Van Loo, R. A. Rastall, and M. B. Roberfroid, "Dietary modulation of the human colonic microbiota: updating the concept of prebiotics," Nutrition Research Reviews, vol. 17, no. 2, pp. 259-275, 2004.

[30] E. Menne, N. Guggenbuhl, and M. Roberfroid, "Fn-type chicory inulin hydrolysate has a prebiotic effect in humans," Journal of Nutrition, vol. 130, no. 5, pp. 1197-1199, 2000.

[31] Y. Bouhnik, B. Flourié, L. D’Agay-Abensour et al., "Administration of transgalacto-oligosaccharides increases fecal bifidobacteria and modifies colonic fermentation metabolism in healthy humans," Journal of Nutrition, vol. 127, no. 3, pp. 444-448, 1997.

[32] M. Ito, Y. Deguchi, K. Matsumoto, M. Kimura, N. Onodera, and T. Yajima, "Influence of galactooligosaccharides on the human fecal microflora," Journal of Nutritional Science and Vitaminology, vol. 39, no. 6, pp. 635-640, 1993.

[33] P. D. Cani, R. Bibiloni, C. Knauf et al., "Changes in gut microbiota control metabolic endotoxemia-induced inflammation in high-fat diet-induced obesity and diabetes in mice," Diabetes, vol. 57, no. 6, pp. 1470-1481, 2008.

[34] N. M. Delzenne, A. M. Neyrinck, and P. D. Cani, "Modulation of the gut microbiota by nutrients with prebiotic properties: consequences for host health in the context of obesity and metabolic syndrome," Microbial Cell Factories, vol. 10, supplement 1, article S10, 2011.

[35] F. Di Bartolomeo, J. B. Startek, and W. van den Ende, "Prebiotics to fight diseases: reality or fiction?" Phytotherapy Research, vol. 27, no. 10, pp. 1457-1473, 2013. 
[36] J. Tarini and T. M. S. Wolever, "The fermentable fibre inulin increases postprandial serum short-chain fatty acids and reduces free-fatty acids and ghrelin in healthy subjects," Applied Physiology, Nutrition and Metabolism, vol. 35, no. 1, pp. 9-16, 2010.

[37] J. J. Rumessen, S. Bodé, O. Hamberg, and E. Gudmand-Høyer, "Fructans of Jerusalem artichokes: intestinal transport, absorption, fermentation, and influence on blood glucose, insulin, and C-peptide responses in healthy subjects," American Journal of Clinical Nutrition, vol. 52, no. 4, pp. 675-681, 1990.

[38] T. van de Wiele, N. Boon, S. Possemiers, H. Jacobs, and W. Verstraete, "Inulin-type fructans of longer degree of polymerization exert more pronounced in vitro prebiotic effects," Journal of Applied Microbiology, vol. 102, no. 2, pp. 452-460, 2007.

[39] D. Dai, N. N. Nanthkumar, D. S. Newburg, and W. A. Walker, "Role of oligosaccharides and glycoconjugates in intestinal host defense," Journal of Pediatric Gastroenterology and Nutrition, vol. 30, supplement 2, pp. S23-S33, 2000.

[40] M. Ortega-González, F. Sánchez De Medina, C. MolinaSantiago et al., "Fructooligosacharides reduce Pseudomonas aeruginosa $\mathrm{PAO} 1$ pathogenicity through distinct mechanisms," PLoS ONE, vol. 9, no. 1, Article ID e85772, 2014.

[41] J. E. Urías-Silvas, P. D. Cani, E. Delmée, A. Neyrinck, M. G. López, and N. M. Delzenne, "Physiological effects of dietary fructans extracted from Agave tequilana Gto. and Dasylirion spp," British Journal of Nutrition, vol. 99, no. 2, pp. 254-261, 2008.

[42] S. G. Sáyago-Ayerdi, R. Mateos, R. I. Ortiz-Basurto et al., "Effects of consuming diets containing Agave tequilana dietary fibre and jamaica calyces on body weight gain and redox status in hypercholesterolemic rats," Food Chemistry, vol. 148, pp. 5459, 2014.

[43] P. A. Santiago-García and M. G. López, "Agavins from Agave angustifolia and Agave potatorum affect food intake, body weight gain and satiety-related hormones (GLP-1 and ghrelin) in mice," Food \& Function, vol. 5, no. 12, pp. 3311-3319, 2014.

[44] M. I. McBurney, P. J. Van Soest, and J. L. Jeraci, "Colonic carcinogenesis: the microbial feast or famine mechanism," Nutrition and Cancer, vol. 10, no. 1-2, pp. 23-28, 1987.

[45] V. De Preter, T. Vanhoutte, G. Huys et al., "Effects of Lactobacillus casei Shirota, Bifidobacterium breve, and oligofructose-enriched inulin on colonic nitrogen-protein metabolism in healthy humans," The American Journal of Physiology-Gastrointestinal and Liver Physiology, vol. 292, no. 1, pp. G358-G368, 2007.

[46] E. Gomez, K. M. Tuohy, G. R. Gibson, A. Klinder, and A. Costabile, "In vitro evaluation of the fermentation properties and potential prebiotic activity of Agave fructans," Journal of Applied Microbiology, vol. 108, no. 6, pp. 2114-2121, 2010.

[47] H. D. Holscher, J. L. Doligale, L. L. Bauer et al., "Gastrointestinal tolerance and utilization of agave inulin by healthy adults," Food \& Function, vol. 5, no. 6, pp. 1142-1149, 2014.

[48] A. R. Lomax and P. C. Calder, "Prebiotics, immune function, infection and inflammation: a review of the evidence," British Journal of Nutrition, vol. 101, no. 5, pp. 633-658, 2009.

[49] K. Yamashita, K. Kawai, and M. Itakura, "Effects of fructooligosaccharides on blood glucose and serum lipids in diabetic subjects," Nutrition Research, vol. 4, no. 6, pp. 961-966, 1984.

[50] P. D. Cani, C. Knauf, M. A. Iglesias, D. J. Drucker, N. M. Delzenne, and R. Burcelin, "Improvement of glucose tolerance and hepatic insulin sensitivity by oligofructose requires a functional glucagon-like peptide 1 receptor," Diabetes, vol. 55, no. 5, pp. 1484-1490, 2006.

[51] A. Everard, V. Lazarevic, M. Derrien et al., "Responses of gut microbiota and glucose and lipid metabolism to prebiotics in genetic obese and diet-induced leptin-resistant mice," Diabetes, vol. 60, no. 11, pp. 2775-2786, 2011.

[52] F. Brighenti, "Dietary fructans and serum triacylglycerols: a meta-analysis of randomized controlled trials," Journal of Nutrition, vol. 137, no. 11, supplement, pp. 2552S-2556S, 2007.

[53] C. Daubioul, N. Rousseau, R. Demeure et al., "Dietary fructans, but not cellulose, decrease triglyceride accumulation in the liver of obese Zucker fa/fa rats," Journal of Nutrition, vol. 132, no. 5, pp. 967-973, 2002.

[54] R. A. Reimer and J. C. Russell, "Glucose tolerance, lipids, and GLP-1 secretion in JCR:LA-cp rats fed a high protein fiber diet," Obesity, vol. 16, no. 1, pp. 40-46, 2008.

[55] E. Sakaguchi, C. Sakoda, and Y. Toramaru, "Caecal fermentation and energy accumulation in the rat fed on indigestible oligosaccharides," British Journal of Nutrition, vol. 80, no. 5, pp. 469-476, 1998.

[56] C. A. Daubioul, H. S. Taper, L. D. de Wispelaere, and N. M. Delzenne, "Dietary oligofructose lessens hepatic steatosis, but does not prevent hypertriglyceridemia in obese Zucker rats," Journal of Nutrition, vol. 130, no. 5, pp. 1314-1319, 2000.

[57] E. Delmée, P. D. Cani, G. Gual et al., "Relation between colonic proglucagon expression and metabolic response to oligofructose in high fat diet-fed mice," Life Sciences, vol. 79, no. 10, pp. 1007-1013, 2006.

[58] J. A. Jamieson, N. R. Ryz, C. G. Taylor, and H. A. Weiler, "Dietary long-chain inulin reduces abdominal fat but has no effect on bone density in growing female rats," British Journal of Nutrition, vol. 100, no. 2, pp. 451-459, 2008.

[59] P. D. Cani, S. Possemiers, T. van de Wiele et al., "Changes in gut microbiota control inflammation in obese mice through a mechanism involving GLP-2-driven improvement of gut permeability," Gut, vol. 58, no. 8, pp. 1091-1103, 2009.

[60] B. Kleessen, S. Schwarz, A. Boehm et al., "Jerusalem artichoke and chicory inulin in bakery products affect faecal microbiota of healthy volunteers," British Journal of Nutrition, vol. 98, no. 3, pp. 540-549, 2007.

[61] S. Wang, H. Zhu, C. Lu et al., "Fermented milk supplemented with probiotics and prebiotics can effectively alter the intestinal microbiota and immunity of host animals," Journal of Dairy Science, vol. 95, no. 9, pp. 4813-4822, 2012.

[62] H. Hidaka, Y. Tashiro, and T. Eida, "Proliferation of bifidobacteria by oligosaccharides and their useful effect on human health," Bifidobacteria and Microflora, vol. 10, no. 1, pp. 65-79, 1991.

[63] J. Li and I. H. Kim, "Effects of levan-type fructan supplementation on growth performance, digestibility, blood profile, fecal microbiota, and immune responses after lipopolysaccharide challenge in growing pigs," Journal of Animal Science, vol. 91, no. 11, pp. 5336-5343, 2013.

[64] Z. Zduńczyk, J. Juśkiewicz, and I. Estrella, "Cecal parameters of rats fed diets containing grapefruit polyphenols and inulin as single supplements or in a combination," Nutrition, vol. 22, no. 9, pp. 898-904, 2006.

[65] J. Busserolles, E. Gueux, E. Rock, C. Demigné, A. Mazur, and Y. Rayssiguier, "Oligofructose protects against the hypertriglyceridemic and pro-oxidative effects of a high fructose diet in rats," Journal of Nutrition, vol. 133, no. 6, pp. 1903-1908, 2003. 
[66] E. G. H. M. van den Heuvel, T. Muys, W. van Dokkum, and G. Schaafsma, "Oligofructose stimulates calcium absorption in adolescents," The American Journal of Clinical Nutrition, vol. 69, no. 3, pp. 544-548, 1999.

[67] H. Younes, C. Coudray, J. Bellanger, C. Demigné, Y. Rayssiguier, and C. Rémésy, "Effects of two fermentable carbohydrates (inulin and resistant starch) and their combination on calcium and magnesium balance in rats," British Journal of Nutrition, vol. 86, no. 4, pp. 479-485, 2001.

[68] K. E. Scholz-Ahrens, P. Ade, B. Marten et al., "Prebiotics, probiotics, and synbiotics affect mineral absorption, bone mineral content, and bone structure," Journal of Nutrition, vol. 137, no. 3 , supplement 2, pp. 838S-846S, 2007.

[69] M. I. García-Vieyra, A. del Real, and M. G. López, "Agave fructans: their effect on mineral absorption and bone mineral content," Journal of Medicinal Food, vol. 17, no. 11, pp. 1247-1255, 2014.

[70] P. Bodera, "Influence of prebiotics on the human immune system (GALT)," Recent Patents on Inflammation and Allergy Drug Discovery, vol. 2, no. 2, pp. 149-153, 2008.

[71] I. R. Sanderson, "Dietary modulation of GALT," Journal of Nutrition, vol. 137, supplement 11, pp. 2557S-2562S, 2007.

[72] L. Mayer, "Mucosal immunity," Pediatrics, vol. 111, no. 6, part 3, pp. 1595-1600, 2003.

[73] T. T. MacDonald and G. Monteleone, "Immunity, inflammation, and allergy in the gut," Science, vol. 307, no. 5717, pp. 1920-1925, 2005.

[74] A. M. Mowat, "Anatomical basis of tolerance and immunity to intestinal antigens," Nature Reviews Immunology, vol. 3, no. 4, pp. 331-341, 2003.

[75] E. Ramiro-Puig, F. J. Pérez-Cano, C. Castellote, A. Franch, and M. Castell, "The bowel: a key component of the immune system," Revista Espanola de Enfermedades Digestivas, vol. 100, no. 1, pp. 29-34, 2008.

[76] M. Rescigno, M. Urbano, B. Valzasina et al., "Dendritic cells express tight junction proteins and penetrate gut epithelial monolayers to sample bacteria," Nature Immunology, vol. 2, no. 4, pp. 361-367, 2001.

[77] B. Jabri and E. Ebert, "Human $\mathrm{CD}^{+}$intraepithelial lymphocytes: a unique model to study the regulation of effector cytotoxic T lymphocytes in tissue," Immunological Reviews, vol. 215, no. 1, pp. 202-214, 2007.

[78] J. H. Niess, S. Brand, X. Gu et al., "CX3CR1-mediated dendritic cell access to the intestinal lumen and bacterial clearance," Science, vol. 307, no. 5707, pp. 254-258, 2005.

[79] H. Cheroutre, "IELs: enforcing law and order in the court of the intestinal epithelium," Immunological Reviews, vol. 206, no. 1, pp. 114-131, 2005.

[80] R. M. Steinman, "Decisions about dendritic cells: past, present, and future," Annual Review of Immunology, vol. 30, no. 1, pp. $1-22,2012$.

[81] J. Shiu and T. G. Blanchard, "Dendritic cell function in the host response to Helicobacter pylori infection of the gastric mucosa," Pathogens and Disease, vol. 67, no. 1, pp. 46-53, 2013.

[82] J. L. Coombes and F. Powrie, "Dendritic cells in intestinal immune regulation," Nature Reviews Immunology, vol. 8, no. 6 , pp. 435-446, 2008.

[83] C. M. Sun, J. A. Hall, R. B. Blank et al., "Small intestine lamina propria dendritic cells promote de novo generation of Foxp3 T reg cells via retinoic acid," Journal of Experimental Medicine, vol. 204, no. 8, pp. 1775-1785, 2007.
[84] S. Uematsu, K. Fujimoto, M. H. Jang et al., "Regulation of humoral and cellular gut immunity by lamina propria dendritic cells expressing Toll-like receptor 5," Nature Immunology, vol. 9, no. 7, pp. 769-776, 2008.

[85] T. L. Denning, B. A. Norris, O. Medina-Contreras et al., "Functional specializations of intestinal dendritic cell and macrophage subsets that control Th17 and regulatory $\mathrm{T}$ cell responses are dependent on the T cell/APC ratio, source of mouse strain, and regional localization," The Journal of Immunology, vol. 187, no. 2, pp. 733-747, 2011.

[86] O. Takeuchi and S. Akira, "Pattern recognition receptors and inflammation," Cell, vol. 140, no. 6, pp. 805-820, 2010.

[87] M. Dalod, R. Chelbi, B. Malissen, and T. Lawrence, "Dendritic cell maturation: functional specialization through signaling specificity and transcriptional programming," The EMBO Journal, vol. 33, no. 10, pp. 1104-1116, 2014.

[88] D. Han, M. C. Walsh, P. J. Cejas et al., "Dendritic cell expression of the signaling molecule TRAF6 is critical for gut microbiotadependent immune tolerance," Immunity, vol. 38, no. 6, pp. 1211-1222, 2013.

[89] X. Chen and J. J. Oppenheim, “Th17 cells and Tregs: unlikely allies," Journal of Leukocyte Biology, vol. 95, no. 5, pp. 723-731, 2014.

[90] G. Reid, J. A. Younes, H. C. van der Mei, G. B. Gloor, R. Knight, and H. J. Busscher, "Microbiota restoration: natural and supplemented recovery of human microbial communities," Nature Reviews Microbiology, vol. 9, no. 1, pp. 27-38, 2011.

[91] T. D. Leser and L. Mølbak, "Better living through microbial action: the benefits of the mammalian gastrointestinal microbiota on the host," Environmental Microbiology, vol. 11, no. 9, pp. 2194-2206, 2009.

[92] S. K. Mazmanian, C. H. Liu, A. O. Tzianabos, and D. L. Kasper, "An immunomodulatory molecule of symbiotic bacteria directs maturation of the host immune system," Cell, vol. 122, no. 1, pp. 107-118, 2005.

[93] W. S. Garrett, J. I. Gordon, and L. H. Glimcher, "Homeostasis and inflammation in the intestine," Cell, vol. 140, no. 6, pp. 859$870,2010$.

[94] I. I. Ivanov and K. Honda, "Intestinal commensal microbes as immune modulators," Cell Host and Microbe, vol. 12, no. 4, pp. 496-508, 2012.

[95] S. K. Mazmanian, J. L. Round, and D. L. Kasper, "A microbial symbiosis factor prevents intestinal inflammatory disease," Nature, vol. 453, no. 7195, pp. 620-625, 2008.

[96] B. Ruiz-Perez, D. R. Chung, A. H. Sharpe et al., "Modulation of surgical fibrosis by microbial zwitterionic polysaccharides," Proceedings of the National Academy of Sciences of the United States of America, vol. 102, no. 46, pp. 16753-16758, 2005.

[97] L. L. Presley, B. Wei, J. Braun, and J. Borneman, "Bacteria associated with immunoregulatory cells in mice," Environmental Microbiology, vol. 76, no. 3, pp. 936-941, 2010.

[98] K. Pokusaeva, G. F. Fitzgerald, and D. van Sinderen, "Carbohydrate metabolism in bifidobacteria," Genes \& Nutrition, vol. 6, no. 3, pp. 285-306, 2011.

[99] M. Blaut, "Relationship of prebiotics and food to intestinal microflora," European Journal of Nutrition, vol. 41, no. 1, pp. 1116, 2002.

[100] A. Barcelo, J. Claustre, F. Moro, J.-A. Chayvialle, J.-C. Cuber, and P. Plaisancié, "Mucin secretion is modulated by luminal factors in the isolated vascularly perfused rat colon," Gut, vol. 46, no. 2, pp. $218-224,2000$. 
[101] A. J. Brown, S. M. Goldsworthy, A. A. Barnes et al., "The orphan G protein-coupled receptors GPR41 and GPR43 are activated by propionate and other short chain carboxylic acids," The Journal of Biological Chemistry, vol. 278, no. 13, pp. 11312-11319, 2003.

[102] E. Le Poul, C. Loison, S. Struyf et al., "Functional characterization of human receptors for short chain fatty acids and their role in polymorphonuclear cell activation," The Journal of Biological Chemistry, vol. 278, no. 28, pp. 25481-25489, 2003.

[103] N. E. Nilsson, K. Kotarsky, C. Owman, and B. Olde, "Identification of a free fatty acid receptor, FFA2R, expressed on leukocytes and activated by short-chain fatty acids," Biochemical and Biophysical Research Communications, vol. 303, no. 4, pp. 1047-1052, 2003.

[104] D. K. Covington, C. A. Briscoe, A. J. Brown, and C. K. Jayawickreme, "The G-protein-coupled receptor 40 family (GPR40GPR43) and its role in nutrient sensing," Biochemical Society Transactions, vol. 34, no. 5, pp. 770-773, 2006.

[105] K. M. Maslowski, A. T. Vieira, A. Ng et al., "Regulation of inflammatory responses by gut microbiota and chemoattractant receptor GPR43," Nature, vol. 461, no. 7268, pp. 1282-1286, 2009.

[106] M. A. R. Vinolo, H. G. Rodrigues, E. Hatanaka, C. B. Hebeda, S. H. P. Farsky, and R. Curi, "Short-chain fatty acids stimulate the migration of neutrophils to inflammatory sites," Clinical Science (Lond), vol. 117, no. 9, pp. 331-338, 2009.

[107] J.-S. Park, E.-J. Lee, J.-C. Lee, W.-K. Kim, and H.-S. Kim, "Anti-inflammatory effects of short chain fatty acids in IFN- $\gamma$ stimulated RAW 264.7 murine macrophage cells: involvement of NF- $\kappa \mathrm{B}$ and ERK signaling pathways," International Immunopharmacology, vol. 7, no. 1, pp. 70-77, 2007.

[108] M. A. R. Vinolo, H. G. Rodrigues, E. Hatanaka, F. T. Sato, S. C. Sampaio, and R. Curi, "Suppressive effect of short-chain fatty acids on production of proinflammatory mediators by neutrophils," Journal of Nutritional Biochemistry, vol. 22, no. 9, pp. 849-855, 2011.

[109] D. J. A. Jenkins, C. W. C. Kendall, and V. Vuksan, "Inulin, oligofructose and intestinal function," Journal of Nutrition, vol. 129, no. 7, pp. 1431S-1433S, 1999.

[110] Y. Sanz, I. Nadal, and E. Sánchez, "Probiotics as drugs against human gastrointestinal infections," Recent Patents on AntiInfective Drug Discovery, vol. 2, no. 2, pp. 148-156, 2007.

[111] L. Vogt, U. Ramasamy, D. Meyer et al., "Immune modulation by different types of beta $\rightarrow 1$-fructans is toll-like receptor dependent," PLoS ONE, vol. 8, no. 7, Article ID e68367, 2013.

[112] L. M. Vogt, D. Meyer, G. Pullens et al., "Toll-like receptor 2 activation by $\beta 2 \rightarrow 1$-fructans protects barrier function of T84 human intestinal epithelial cells in a chain length-dependent manner," Journal of Nutrition, vol. 144, no. 7, pp. 1002-1008, 2014.

[113] N. R. Ryz, J. B. Meddings, and C. G. Taylor, "Long-chain inulin increases dendritic cells in the Peyer's patches and increases ex vivo cytokine secretion in the spleen and mesenteric lymph nodes of growing female rats, independent of zinc status," British Journal of Nutrition, vol. 101, no. 11, pp. 1653-1663, 2009.

[114] J. Herre, S. Gordon, and G. D. Brown, "Dectin-1 and its role in the recognition of $\beta$-glucans by macrophages," Molecular Immunology, vol. 40, no. 12, pp. 869-876, 2004.

[115] M. E. Taylor, J. T. Conary, M. R. Lennartz, P. D. Stahl, and K. Drickamer, "Primary structure of the mannose receptor contains multiple motifs resembling carbohydrate-recognition domains," The Journal of Biological Chemistry, vol. 265, no. 21, pp. 12156-12162, 1990.
[116] A. C. Ouwehand, M. Derrien, W. de Vos, K. Tiihonen, and N. Rautonen, "Prebiotics and other microbial substrates for gut functionality," Current Opinion in Biotechnology, vol. 16, no. 2, pp. 212-217, 2005.

[117] J. H. Cummings, G. T. Macfarlane, and H. N. Englyst, "Prebiotic digestion and fermentation," The American Journal of Clinical Nutrition, vol. 73, no. 2, supplement, pp. 415S-420S, 2001.

[118] H. R. Gaskins, R. I. Mackie, T. May, and K. A. Garleb, “Dietary fructo-oligosaccharide modulates large intestinal inflammatory responses to Clostridium difficile in antibiotic-compromised mice," Microbial Ecology in Health \& Disease, vol. 9, no. 4, pp. 157-166, 1996.

[119] C. J. Field, M. I. McBurney, S. Massimino, M. G. Hayek, and G. D. Sunvold, "The fermentable fiber content of the diet alters the function and composition of canine gut associated lymphoid tissue," Veterinary Immunology and Immunopathology, vol. 72, no. 3-4, pp. 325-341, 1999.

[120] A. Letellier, S. Messier, L. Lessard, S. Chénier, and S. Quessy, "Host response to various treatments to reduce salmonella infections in swine," Canadian Journal of Veterinary Research, vol. 65, no. 3, pp. 168-172, 2001.

[121] R. Herich, V. Révajová, M. Levkut et al., "The effect of Lactobacillus paracasei and Raftilose P95 upon the non-specific immune response of piglets," Food and Agricultural Immunology, vol. 14, pp. 171-179, 2002.

[122] K. S. Swanson, C. M. Grieshop, E. A. Flickinger et al., "Supplemental fructooligosaccharides and mannanoligosaccharides influence immune function, ileal and total tract nutrient digestibilities, microbial populations and concentrations of protein catabolites in the large bowel of dogs," Journal of Nutrition, vol. 132, no. 5, pp. 980-989, 2002.

[123] K. S. Swanson, C. M. Grieshop, E. A. Flickinger et al., "Effects of supplemental fructooligosaccharides plus mannanoligosaccharides on immune function and ileal and fecal microbial populations in adult dogs," Archiv für Tierernährung, vol. 56, no. 4, pp. 309-318, 2002.

[124] H. Qiao, L. C. Duffy, E. Griffiths et al., "Immune responses in rhesus rotavirus-challenged Balb/c mice treated with bifidobacteria and prebiotic supplements," Pediatric Research, vol. 51, no. 6, pp. 750-755, 2002.

[125] D. Bunout, S. Hirsch, M. P. de la Maza et al., "Effects of prebiotics on the immune response to vaccination in the elderly," Journal of Parenteral and Enteral Nutrition, vol. 26, no. 6, pp. 372-376, 2002.

[126] Y. Guigoz, F. Rochat, G. Perruisseau-Carrier, I. Rochat, and E. J. Schiffrin, "Effects of oligosaccharide on the faecal flora and nonspecific immune system in elderly people," Nutrition Research, vol. 22, no. 1-2, pp. 13-25, 2002.

[127] A. Hosono, A. Ozawa, R. Kato et al., "Dietary fructooligosaccharides induce immunoregulation of intestinal IgA secretion by murine peyer's patch cells," Bioscience, Biotechnology and Biochemistry, vol. 67, no. 4, pp. 758-764, 2003.

[128] K. A. Kelly-Quagliana, P. D. Nelson, and R. K. Buddington, "Dietary oligofructose and inulin modulate immune functions in mice," Nutrition Research, vol. 23, no. 2, pp. 257-267, 2003.

[129] N. Manhart, A. Spittler, H. Bergmeister, M. Mittlböck, and E. Roth, "Influence of fructooligosaccharides on Peyer's patch lymphocyte numbers in healthy and endotoxemic mice," Nutrition, vol. 19, no. 7-8, pp. 657-660, 2003.

[130] C. M. Grieshop, E. A. Flickinger, K. J. Bruce, A. R. Patil, G. L. Czarnecki-Maulden, and G. C. Fahey Jr., "Gastrointestinal 
and immunological responses of senior dogs to chicory and mannan-oligosaccharides," Archives of Animal Nutrition, vol. 58, no. 6, pp. 483-493, 2004.

[131] Y. Nakamura, S. Nosaka, M. Suzuki et al., "Dietary fructooligosaccharides up-regulate immunoglobulin A response and polymeric immunoglobulin receptor expression in intestines of infant mice," Clinical \& Experimental Immunology, vol. 137, no. 1, pp. 52-58, 2004.

[132] M. Roller, G. Rechkemmer, and B. Watzl, "Prebiotic Inulin Enriched with Oligofructose in Combination with the Probiotics Lactobacillus rhamnosus and Bifidobacterium lactis modulates intestinal immune Functions in Rats," Journal of Nutrition, vol. 134, no. 1, pp. 153-156, 2004.

[133] D. Bunout, G. Barrera, S. Hirsch et al., "Effects of a nutritional supplement on the immune response and cytokine production in free-living Chilean elderly," Journal of Parenteral and Enteral Nutrition, vol. 28, no. 5, pp. 348-354, 2004.

[134] B. Langkamp-Henken, B. S. Bender, E. M. Gardner et al., "Nutritional formula enhanced immune function and reduced days of symptoms of upper respiratory tract infection in seniors," Journal of the American Geriatrics Society, vol. 52, no. 1, pp. 3-12, 2004.

[135] E. N. Trushina, E. A. Martynova, D. B. Nikityk, O. K. Mustafina, and E. K. Baygarin, "The influence of dietary inulin and oligofructose on the cell-mediated and humoral immunity in rats," Voprosy Pitaniia, vol. 74, no. 3, pp. 22-27, 2005.

[136] A. M. Bakker-Zierikzee, E. A. F. van Tol, H. Kroes, M. S. Alles, F. J. Kok, and J. G. Bindels, "Faecal SIgA secretion in infants fed on pre- or pro-biotic infant formula," Pediatric Allergy and Immunology, vol. 17, no. 2, pp. 134-140, 2006.

[137] B. Langkamp-Henken, S. M. Wood, K. A. Herlinger-Garcia et al., "Nutritional formula improved immune profiles of seniors living in nursing homes," Journal of the American Geriatrics Society, vol. 54, no. 12, pp. 1861-1870, 2006.

[138] V. Adogony, F. Respondek, V. Biourge et al., "Effects of dietary scFOS on immunoglobulins in colostrums and milk of bitches," Journal of Animal Physiology and Animal Nutrition, vol. 91, no. 5-6, pp. 169-174, 2007.

[139] C. J. Apanavicius, K. L. Powell, B. M. Vester et al., "Fructan supplementation and infection affect food intake, fever, and epithelial sloughing from salmonella challenge in weanling puppies," Journal of Nutrition, vol. 137, no. 8, pp. 1923-1930, 2007.

[140] C. Seidel, V. Boehm, H. Vogelsang et al., "Influence of prebiotics and antioxidants in bread on the immune system, antioxidative status and antioxidative capacity in male smokers and nonsmokers," British Journal of Nutrition, vol. 97, no. 2, pp. 349-356, 2007.

[141] J. Benyacoub, F. Rochat, K.-Y. Saudan et al., "Feeding a diet containing a fructooligosaccharide mix can enhance Salmonella vaccine efficacy in mice," Journal of Nutrition, vol. 138, no. 1, pp. 123-129, 2008.

[142] P. A. M. J. Scholtens, P. Alliet, M. Raes et al., "Fecal secretory immunoglobulin A is increased in healthy infants who receive a formula with short-chain galacto-oligosaccharides and longchain fructo-oligosaccharides," Journal of Nutrition, vol. 138, no. 6, pp. 1141-1147, 2008.

[143] J. Vulevic, A. Drakoularakou, P. Yaqoob, G. Tzortzis, and G. R. Gibson, "Modulation of the fecal microflora profile and immune function by a novel trans-galactooligosaccharide mixture (B-GOS) in healthy elderly volunteers," The American Journal of Clinical Nutrition, vol. 88, no. 5, pp. 1438-1446, 2008.
[144] E. van Hoffen, B. Ruiter, J. Faber et al., "A specific mixture of short-chain galacto-oligosaccharides and long-chain fructooligosaccharides induces a beneficial immunoglobulin profile in infants at high risk for allergy," Allergy, vol. 64, no. 3, pp. 484487, 2009.

[145] Y. Li, Y. Zong, J. Qi, and K. Liu, "Prebiotics and oxidative stress in constipated rats," Journal of Pediatric Gastroenterology and Nutrition, vol. 53, no. 4, pp. 447-452, 2011.

[146] G. T. Choque Delgado, R. Thomé, D. L. Gabriel, W. M. S. C. Tamashiro, and G. M. Pastore, "Yacon (Smallanthus sonchifolius)-derived fructooligosaccharides improves the immune parameters in the mouse," Nutrition Research, vol. 32, no. 11, pp. 884-892, 2012.

[147] J.-M. Lecerf, F. Dépeint, E. Clerc et al., "Xylo-oligosaccharide (XOS) in combination with inulin modulates both the intestinal environment and immune status in healthy subjects, while XOS alone only shows prebiotic properties," British Journal of Nutrition, vol. 108, no. 10, pp. 1847-1858, 2012.

[148] J. Vulevic, A. Juric, G. Tzortzis, and G. R. Gibson, "A mixture of trans-galactooligosaccharides reduces markers of metabolic syndrome and modulates the fecal microbiota and immune function of overweight adults1-3," The Journal of Nutrition, vol. 143, no. 3, pp. 324-331, 2013.

[149] G. Bouchaud, L. Castan, J. Chabauty, P. Aubert, M. Neunlist, and M. Bodinier, "11: perinatal exposure to galactooligosaccharides/inulin prebiotics prevent food allergy by protecting intestine and promoting tolerance," Cytokine, vol. 70, no. 1, 30 pages, 2014.

[150] C. E. Childs, H. Röytiö, E. Alhoniemi et al., "Xylooligosaccharides alone or in synbiotic combination with Bifidobacterium animalis subsp. lactis induce bifidogenesis and modulate markers of immune function in healthy adults: a double-blind, placebo-controlled, randomised, factorial crossover study," British Journal of Nutrition, vol. 111, no. 11, pp. 1945-1956, 2014.

[151] L. Samal, V. B. Chaturvedi, G. Saikumar, R. Somvanshi, and A. K. Pattanaik, "Prebiotic potential of Jerusalem artichoke (Helianthus tuberosus L.) in Wistar rats: effects of levels of supplementation on hindgut fermentation, intestinal morphology, blood metabolites and immune response," Journal of the Science of Food and Agriculture, 2014.

[152] A. Huazano-García and M. G. López, "Metabolism of short chain fatty acids in colon and faeces of mice after a supplementation of diets with agave fructans," in Lipid Metabolism, R. Valenzuela Baez, Ed., vol. 8, pp. 163-182, InTech, Rijeka, Croatia, 2013.

[153] S. K. Chen, M. L. Tsai, J. R. Huang, and R. H. Chen, "In vitro antioxidant activities of low-molecular-weight polysaccharides with various functional groups," Journal of Agricultural and Food Chemistry, vol. 57, no. 7, pp. 2699-2704, 2009.

[154] E. Hernandez-Marin and A. Martínez, "Carbohydrates and their free radical scavenging capability: a theoretical study," Journal of Physical Chemistry B, vol. 116, no. 32, pp. 9668-9675, 2012.

[155] E. Keunen, D. Peshev, J. Vangronsveld, W. van den Ende, and A. Cuypers, "Plant sugars are crucial players in the oxidative challenge during abiotic stress: extending the traditional concept," Plant, Cell and Environment, vol. 36, no. 7, pp. 1242-1255, 2013.

[156] W. Van den Ende and D. Peshev, "Sugars as antioxidants in plants," in Crop Improvement Under Adverse Conditions, N. Tuteja and S. S. Gill, Eds., pp. 285-307, Springer, New York, NY, USA, 2013. 
[157] D. Peshev, R. Vergauwen, A. Moglia, É. Hideg, and W. Van den Ende, "Towards understanding vacuolar antioxidant mechanisms: a role for fructans?" Journal of Experimental Botany, vol. 64, no. 4, pp. 1025-1038, 2013.

[158] C. H. Foyer, M. Lelandais, and K. J. Kunert, "Photooxidative stress in plants," Physiologia Plantarum, vol. 92, no. 4, pp. 696717, 1994.

[159] A. Nishizawa, Y. Yabuta, and S. Shigeoka, "Galactinol and raffinose constitute a novel function to protect plants from oxidative damage," Plant Physiology, vol. 147, no. 3, pp. 12511263, 2008.

[160] S. Stoyanova, J. Geuns, É. Hideg, and W. Van den Ende, "The food additives inulin and stevioside counteract oxidative stress," International Journal of Food Sciences and Nutrition, vol. 62, no. 3, pp. 207-214, 2011.

[161] X. M. Li, Y. H. Shi, F. Wang, H. S. Wang, and G. W. Le, "In vitro free radical scavenging activities and effect of synthetic oligosaccharides on antioxidant enzymes and lipid peroxidation in aged mice," Journal of Pharmaceutical and Biomedical Analysis, vol. 43, no. 1, pp. 364-370, 2007.

[162] M. Glei, T. Hofmann, K. Küster, J. Hollmann, M. G. Lindhauer, and B. L. Pool-Zobel, "Both wheat (Triticum aestivum) bran arabinoxylans and gut flora-mediated fermentation products protect human colon cells from genotoxic activities of 4hydroxynonenal and hydrogen peroxide," Journal of Agricultural and Food Chemistry, vol. 54, no. 6, pp. 2088-2095, 2006.

[163] J. Juśkiewicz, Z. Zduńczyk, E. Zary-Sikorska, B. Król, J. Milala, and A. Jurgoński, "Effect of the dietary polyphenolic fraction of chicory root, peel, seed and leaf extracts on caecal fermentation and blood parameters in rats fed diets containing prebiotic fructans," British Journal of Nutrition, vol. 105, no. 5, pp. 710720, 2011. 


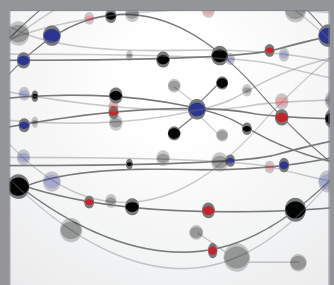

The Scientific World Journal
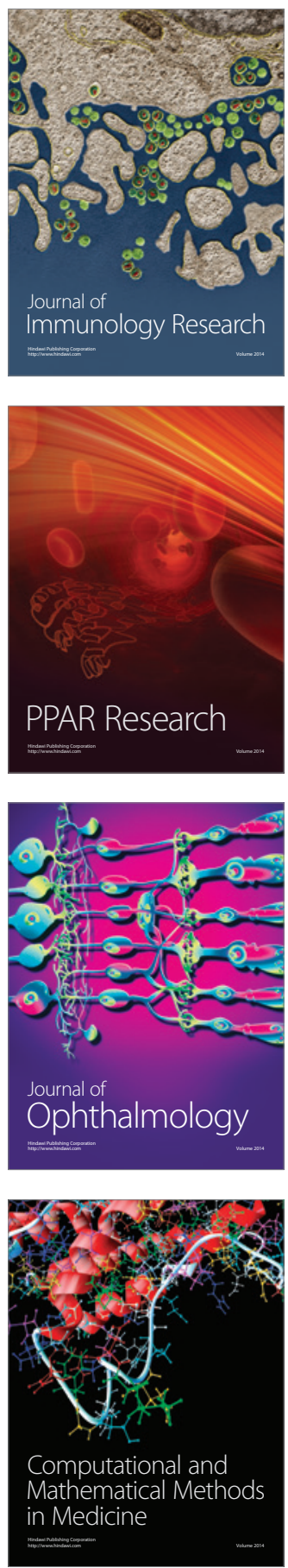

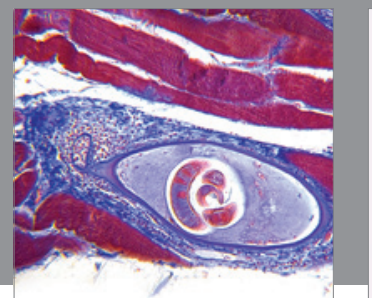

Gastroenterology

Research and Practice
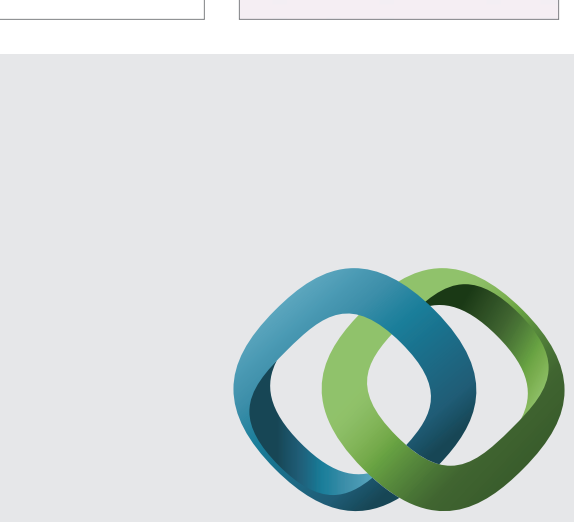

\section{Hindawi}

Submit your manuscripts at

http://www.hindawi.com
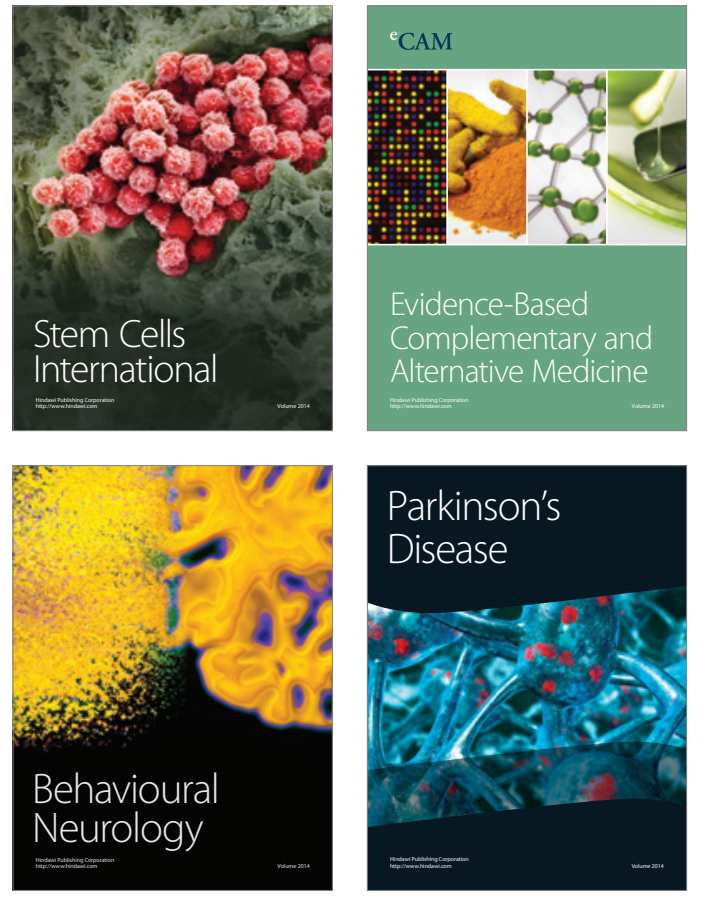
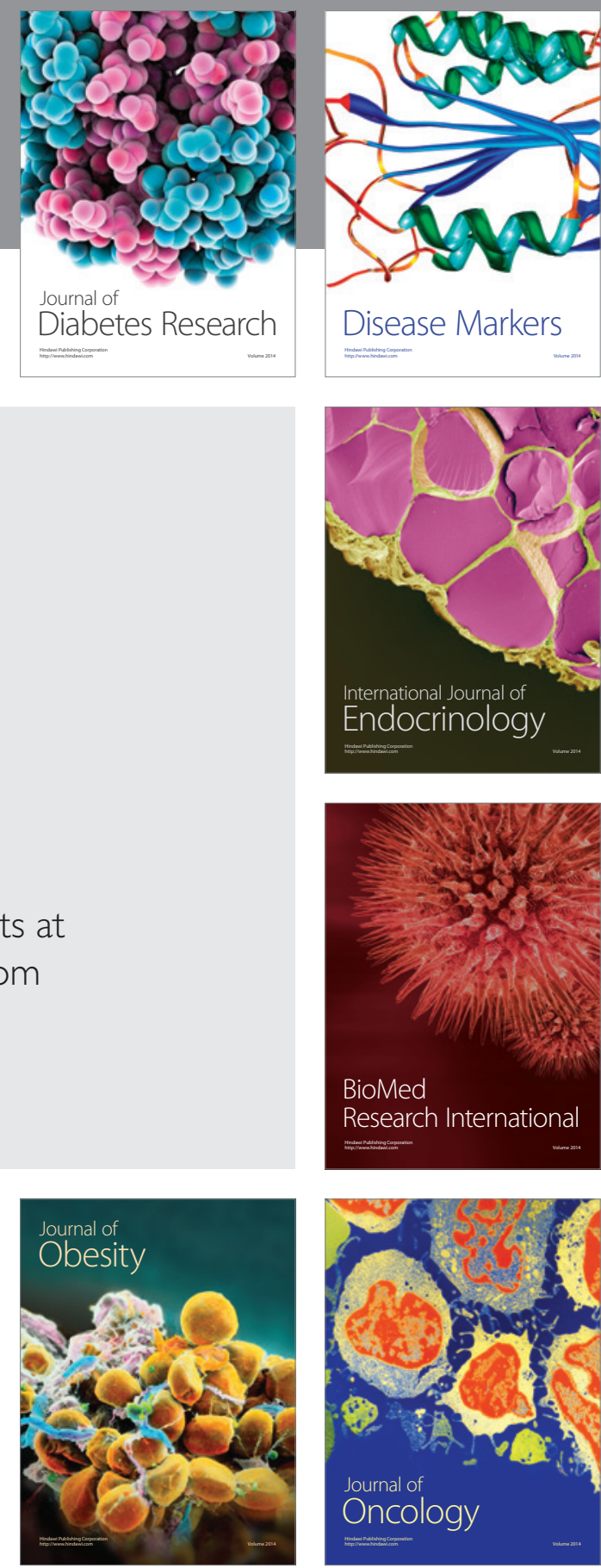

Disease Markers
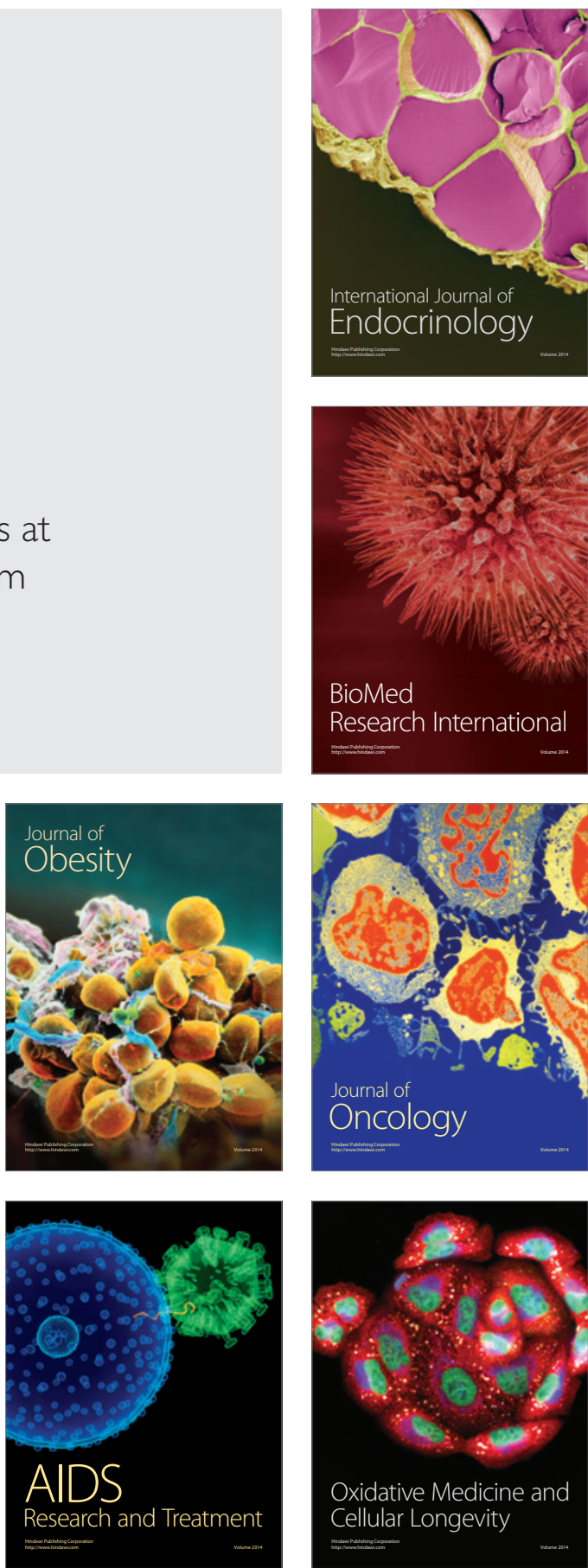